\title{
Agenda Setting at the FASB: Evidence from the Role of the FASAC
}

\section{Citation}

Allen, Abigail. "Agenda Setting at the FASB: Evidence from the Role of the FASAC." Harvard Business School Working Paper, No. 15-042, December 2014.

\section{Permanent link}

http://nrs.harvard.edu/urn-3:HUL.InstRepos:13479079

\section{Terms of Use}

This article was downloaded from Harvard University's DASH repository, and is made available under the terms and conditions applicable to Open Access Policy Articles, as set forth at http:// nrs.harvard.edu/urn-3:HUL.InstRepos:dash.current.terms-of-use\#OAP

\section{Share Your Story}

The Harvard community has made this article openly available.

Please share how this access benefits you. Submit a story.

\section{Accessibility}




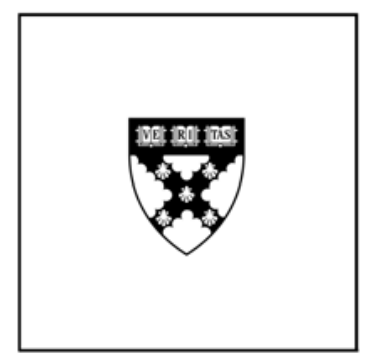

\title{
Agenda Setting at the FASB: Evidence from the Role of the FASAC
}

\author{
Abigail Allen
}

\section{Working Paper}

15-042

December 2, 2014 


\title{
Agenda Setting at the FASB: Evidence from the Role of the FASAC*
}

\author{
Abigail Allen ${ }^{\dagger}$ \\ Harvard Business School \\ Soldiers Field Park \\ Morgan 369 \\ Boston MA 02163
}

This draft: October 30, 2014

\begin{abstract}
I examine the extent to which the FASB's agenda determination is a function of the contemporaneous preferences of its primary constituents: auditors, preparers, and financial statement users. Using the FASB's consultation with the FASAC as a lens through which to view constituent preferences, I find evidence that from 1982 to 2001 influence on FASB agenda decisions is concentrated among "Big N" audit firms, whereas from 2002 to 2006 the preferences of financial constituents appear most significant. Across both periods, I find no evidence of significant preparer influence in agenda formation, which is in contrast to their documented role in later stages of standard setting. Collectively, the results contribute to our understanding of the influence of constituents in standard setting and highlight a shift in that influence over time.
\end{abstract}

\footnotetext{
* This paper is based on my dissertation. I would like to thank my dissertation committee members: Paul Healy, Krishna Palepu, and Karthik Ramanna for their direction, dedication and invaluable advice. For helpful insights and suggestions I would also like to thank: Mary Barth, Dennis Beresford, Alicia Posta, Jeff Wilks, and seminar participants at Baruch College, Harvard Business School, Massachusetts Institute of Technology, Stanford GSB, UC Berkeley, University of Southern California and University of Utah; for generous assistance with sourcing of data, Ron Guerette, Alicia Posta, Stacey Sutay, Betsy Turner, and the FAF. I appreciate the financial support of Harvard Business School.

†Email: aallen@ @bs.edu. Phone: 617-495-6222
} 


\section{Introduction}

The formation of a regulatory agenda is of critical import to the regulated; determination of the agenda dictates regulatory direction and, ergo, the economic costs and benefits that may accrue to the regulated (Arrow 1951, Plott 1976). Accordingly, self-interested constituents have strong incentives to lobby for agenda admission of regulatory initiatives projected to be netbeneficial and exclusion of projects expected to result in net costs. Within accounting, prior research has explored the influence of constituent lobbying in the determination of US GAAP; however, this literature has focused primarily on the exposure draft to final standard stage due to data availability in the form of constituent comment letters (e.g. Watts and Zimmerman 1978). By contrast, the agenda setting process is largely characterized by archival opacity, severely limiting the development of empirical research, despite recognition by that agenda setting is potentially the most "crucial determinant of accounting standards" (Gipper et al 2013), yet remains "one of the least understood and least appreciated" (Beresford 1993). ${ }^{1}$

In this paper, I utilize hand-collected data to shed light on the political dynamics that surround FASB agenda decisions and provide exploratory empirical evidence on the influence of constituent lobbying on FASB project selection. In particular, this paper explores the "balance" between the competing preferences of auditors, preparers and financial statement users and asks whether such "balance" has changed over time.

To obtain an archival perspective on constituent preferences, I leverage a unique institutional feature of the FASB's agenda setting process: formal consultation with an advisory council (FASAC) composed of auditors, preparers, and financial statement users

\footnotetext{
${ }^{1}$ Gipper et al. (2013) note that with the exception of Leftwich (1995), marked preliminary and incomplete, this paper is the first to provide empirical evidence on FASB agenda decisions. Leftwich (1995) was unable to discern systematic patterns in FASB agenda decisions between 1978 and 1995, concluding that future research is needed.
} 
proportionately selected to "represent the Board's constituency in microcosm" (FAF 1984) and charged to advise the FASB regarding its "agenda of projects and the assigning of priorities thereto" (FASB 1973). Formally, FASAC opinions are solicited through an annual survey on the "Priorities of the FASB" (hereafter, FASAC Survey), which affords construction of a quantitative measure of contemporaneously expressed constituent agenda preferences. Although there are other avenues for constituent communication, the FASB asserts that, "given its broad membership, which mirrors the Board's key constituencies, there is a special significance to the Council's assessment" (FAF 1986). Accordingly, data on FASAC preferences constitute a unique vantage from which to estimate the broader political dynamics surrounding FASB's agenda decisions.

A common limitation to lobbying studies is the difficulty of assessing ex-ante regulator preferences. Absent such a measure, studies rely on alignment of policy outcomes with constituent lobbying as evidence of influence (or stronger capture), while ignoring the possibility that such outcomes might simply reflect the independent preferences of regulators. Analysis of FASAC surveys provides a unique opportunity to overcome this barrier; for a subset of years, FASAC Surveys polled FASB members in tandem with FASAC members, enabling me to directly control for the Board's ex-ante preferences in tests of constituent influence.

The present study analyzes 323 agenda decisions made by the FASB from 1982 to 2006 for which an explicit numerical priority rating from FASAC members is available from the Summary of Responses to the FASAC Survey. My initial tests regress the FASB's decision to include a potential project in its technical agenda on the average priority rating assigned to that project by FASAC members while controlling for FASB member ex-ante preferences. Due to a change in survey structure in 2002 (detailed in Section 3.1), my analysis is split into two panels: 
1982-2001 and 2002-2006. Results from both samples provide support for the hypothesis that constituent' preferences matter, on average, in determination of the board's agenda, and that FASAC member priorities provide a meaningful proxy through which to detect influence.

The second stage of my analysis involves building a biographical database of the professional affiliations of all 242 FASAC members who served between 1982 and 2006. Drawing on prior literature, I classify FASAC members into the three primary groups - auditors, preparers, and financial constituents-viewed as having distinctly different incentives and priorities for accounting standards (e.g. Cyert and Ijiri 1974) ${ }^{2}$. Although the FASB expressly commits, in its conceptual framework and elsewhere, to prioritize the needs of investors, creditors, and other financial statement users (broadly termed financial constituents), they have also committed to "balancing" need demands of a diverse constituency, and extant literature has illustrated the potential influence of auditors, (Haring 1979, Puro 1985) and preparers (Saemann 1995, Ramanna 2008) on standard setting outcomes. It is thus unclear, ex-ante, which (if any) group's preferences will manifest in FASB agenda decisions. Moreover, longitudinal evidence of constituent influence across issues and over time is lacking in current literature. Prior empirical studies examine only a small subsample of accounting topics-usually a single issue. However, lobbying is likely a multi-period game, making it difficult to draw wide inferences from what is observed in a single period (Amershi, Demski, and Wolfson 1982). The aim of this paper is to provide systematic longitudinal evidence on whether the FASB has, on average, "balanced" the

\footnotetext{
${ }^{2}$ Consistent with the FASB's classification of financial statement users in FAF annual reports, financial is defined as members associated with the banking, insurance, or securities industries. However, as discussed later in 2.3.2 it is unclear whether the incentives of financial constituents will stem from their role as users or preparers; accordingly the term financial rather than user is employed in my classification of FASAC members.
} 
needs of its constituents in its agenda decisions, or whether the preferences of certain constituents appear persistently dominant.

In particular economic theory suggests that successful lobbying necessitates the mobilization of both political and economic resources to become informed about agenda issues, to secure preferential access to regulators and to influence (or coerce) those regulators to adopt preferred positions (Becker 1983; Austen-Smith 1987; 1993; 1995). Acknowledging this likelihood, in the third stage of analysis, I further hone my classification of FASAC members by size. Specifically, I test for differential influence of the Big N audit firms, Fortune 500 companies and large financial institutions relative to their smaller counterparts. Since its inception the FASB has been subject to criticisms asserting capture by these powerful entities (e.g. US Congress 1976), however dominance of such constituents is not a foregone conclusion. Representational organizations may constitute a powerful lobbying channel for the views of smaller constituents, as might the SEC who has historically advocated the needs of unsophisticated, smaller investors.

From 1982 to 2001, I find evidence that auditor preferences are afforded significantly greater weight in the FASB's selection of agenda projects than are the preferences of financial constituents and preparers. Although less influential than auditors, results suggest financial constituents' preferences also matter, potentially indicative of some degree of "balance" in the FASB's agenda setting. However such "balance" appears to exclude preparers; across specifications I fail to find any evidence of preparer influence. Moreover, after disaggregating constituencies" by size I find no evidence of "balance" in FASB agenda decisions. Once constituencies are disaggregated by size, regression results suggest influence is exclusively 
concentrated in the hands of those historically accused of undue influence, namely, Big $\mathrm{N}$ audit firms.

Separate regression results suggest a marked shift in FASB agenda priorities post 2002. From 2002-2006, only the preferences of financial constituents appear significant in FASB agenda decisions; auditor preferences are insignificant across all specifications as are the preference of preparers. Likewise, disaggregation of constituents by size yields no evidence of Big $\mathrm{N}$ auditor influence. Notably, analysis by size suggests the influence of financial constituents is attributable to both large and small financial representatives, contrary to expectations of dominance by those endowed with greater economic resources but potentially consistent with increasing regulatory emphasis on prioritizing the needs of all users.

The split sample design of my results precludes direct causal analysis, however, the ascendency of financial (relative to auditor) preferences post 2002 is consistent with the increasing influence of the financial industry on standard setting, as documented in Allen and Ramanna (2013). Additionally, the diminished influence of auditors post 2002 may be congruous with regulatory and institutional initiatives designed to bolster the FASB's independence from special interests and increase user influence in standard setting including, the independent funding provisions of Sarbanes Oxley ${ }^{3}$ and the establishment of several new user advisory committees to the FASB. ${ }^{4}$ However, the institutions representing financial constituents may, themselves, constitute a special interest rather than pure user group (e.g. Young 2006, Lev 1988), and there are numerous other factors which may have affected this shift in relative

\footnotetext{
${ }^{3}$ SOX $\$ 109$ provides funding for the FASB through a mandatory accounting fee imposed on US companies, and replaced a voluntary contributions structure that potentially rendered the FASB financially beholden to Big N auditors and large preparers for a significant portion of its annual operating funds.

${ }^{4}$ Between 2003 and 2005, the FASB established the Users Advisory Council, Investors Technical Advisory Committee, and Investors Task Force with the intent to increase user participation in its due process.
} 
constituent influence. Disentangling these alternative factors is not possible in the confines of my archival dataset; notwithstanding, the evidence presented in this paper can provide a useful starting point for future research.

Results of my analysis are robust to the inclusion of numerous substantive and econometric controls including, among others, controls for the influence of the Securities and Exchange Commission, concurrent development of International Accounting Standards and related convergence initiatives, media attention, and year fixed effects.

The rest of the paper is organized as follows. Section 2 provides institutional background on the FASAC and on the FASB's agenda decision process and develops related hypotheses. Section 3 describes the sample selection and construction of variables. Section 4 presents descriptive statistics and multivariate regression design. Section 5 presents and interprets multivariate results. Section 6 describes robustness tests, and Section 7 concludes.

\section{Institutional background and hypothesis development}

\subsection{FASB agenda decisions and constituent influence}

The FASB screens far more topics than there are resources available to address and, consequently, in any given year, rejects the vast majority of potential agenda items (Beresford 1993). Of those items which do make the agenda, a high percentage progress through to completion; of 67 agenda items added between 1982 and 2006 only 4 (6\%) are subsequently dropped while the remaining 63 projects have generated over 100 authoritative standards to date, highlighting the significance of agenda control on regulatory outcome.

Admission to the FASB's agenda is by Board consensus utilizing the following factors about potential agenda topics to guide the FASB's analysis: the pervasiveness of the issue, alternative solutions, technical feasibility, practical consequences, convergence/ cooperative 
opportunities and resources. The FASB further asserts that it is a neutral and independent regulator "weigh[ing] carefully the views of its constituents" in pursuit of "on balance judgments" (Brown 1984). Leftwich (1995) notes, however, that agenda decisions are largely subjective; there is likely little agreement among users, preparers, and auditors about what constitutes a problem, what level of diversity in practice is appropriate, or whether a conceived alternative solution will improve financial reporting. The economic consequences of changes in accounting standards are rarely evenly distributed across the FASB's constituents (e.g., Watts and Zimmerman 1978, Holthausen and Leftwich 1983, Fields, Lys, and Vincent 2001) and it is unlikely, even in theory, that a change in accounting standards will be uniformly preferred by all participants in the economy (Demski 1973).

Preparers, bearing the brunt of implementation costs and concerned about a potential reduction in reporting flexibility, may rationally exhibit a high propensity to oppose accounting change and may overemphasize potential economic costs of any new standard. Ceteris paribus, preparers also prefer greater latitude for management judgment..$^{5}$ Auditors', on the other hand, may strategically lobby for accounting change; proliferation of new standards may increase demand for audit services and professional expertise. ${ }^{6}$ Likewise, promulgation of proscriptive standards may curb management opportunities for discretion, and decrease auditors' potential legal liability. Finally, financial statement users may have incentives to advocate for accounting change; standards that provide new decision-useful information or increase the reliability of existing information benefit users. The construct of a pure user group may, however, be

\footnotetext{
${ }^{5}$ Preference for flexibility does not necessarily imply perverse incentives to mislead investors. Preparers argue that users are best served by management best practices tailored to a firm's underlying economics

${ }^{6}$ The preferences of auditors may be influenced by the preferences of their clients; however, such alignment is presumed strategic: audit firms lobby directly in their own interests which may converge or diverge from those of their clients (Watts and Zimmerman 1982, Puro 1984, Allen, Ramanna and Roychowdhury 2014).
} 
idealistic (e.g., Young 2006) and the FASB itself has historically expressed frustration over the scarcity of user participation in its processes (Beresford 1993). In practice, users are represented on the FASAC by financial firms in the "banking, securities and insurance industries" (collectively financial). Many of these firms are themselves also preparers of financial statements and may advocate on certain issues accordingly, potentially obfuscating the link between financial constituents and the pure user interests the FASB seeks to promote. Thus, it is unclear ex-ante how the FASB should balance the competing needs of its diverse constituency and ex-post how it could be evaluated for success on this criterion.

Adding to the challenge of "balancing", looms the possibility that FASB decisions may be over-ruled by the SEC or Congress, that its standard setting authority may be revoked, or that financial or institutional viability of the organization may be undermined if the FASB is deemed to be insufficiently responsive to the needs of its constituents. These pragmatic institutional concerns likely create political barriers to neutral "optimization" of the agenda even if such objective function could be clearly defined. Additionally, FASB members may have pre-existing ideological biases stemming from their past employment that translate into systematically different priorities in optimizing over various constituencies' preferences (e.g. Allen and Ramanna 2013), and may attenuate the potential for uneven distributional outcomes.

Across its history, the FASB has repeatedly been accused by disgruntled constituents and regulators that it is insufficiently responsive to aggregate public interest or at the extreme that its agenda has been subject to regulatory capture. Evidence to support these claims, however, has been mixed as well as limited by data constraints to only a small subset of FASB decisions. ${ }^{7}$ The

\footnotetext{
${ }^{7}$ Examining a small sample of exposure drafts, Haring (1979) and Puro (1985) find evidence that FASB decisions reflect the preferences of the large accounting firms, whereas Brown (1981) does not and Hussein and Ketz (1980)
} 
intent of this paper is to provide evidence on systematic constituent influence over the FASB's history, and to offer insights into how the relative balancing of constituent preferences may have shifted over time. In addition to constituent preferences, the FASB's agenda is undoubtedly responsive to numerous other economic, legal and political trends. ${ }^{8}$ These forces are likely embedded in constituent preferences; however, it is outside the scope of this study to estimate their direct effects.

\subsection{The Financial Accounting Standards Advisory Council}

Constituent participation in the FASB's agenda setting process is institutionalized through the Financial Accounting Standards Advisory Council (FASAC), established concurrent with the FASB in 1973 and tasked to advise the Board concerning the addition and prioritization of projects to its technical agenda (FASB 1978). FASAC members serve part time and, are selected by the FASB's parent organization (the FAF) on the basis of professional affiliation to ensure that the Council remains "broadly representative of preparers, auditors, and users of financial information" in their respective constituencies (FASB 2007). In communicating with the FASB, FASAC members are encouraged to share materials with and solicit views from their associates to increase the representativeness of its input. The FASB asserts that it relies on FASAC to provide a "window through which the Board can obtain and discuss the representative views of the[se] diverse groups" (FASB 2013) and that it "would not add [any] major project to its agenda without first discussing that project with FASAC" (FAF 1996).

report mixed evidence. More recently Saemann (1995) and Ramanna (2008) find evidence of the FASB yielding to preparers' demands in formulation specific final standards.

${ }^{8}$ For example, Bertomeu and Magee (2011) develop a model in which the agenda of accounting regulators is a function of economic cycles and political demands. 
Formally, FASAC agenda priorities are solicited at quarterly meetings with the FASB and though an annual survey entitled "Projects and Priorities of the FASB" (hereafter, FASAC Survey). From 1982 to 2001 the FASAC Survey solicited quantitative ratings from members for a selective amalgamation of potential projects brought to the FASB's attention throughout the year by the FASAC, Emerging Issues Task Force (EITF), SEC, and any other constituents. From 2002 to 2006, in lieu of a list, FASAC members were asked to identify on a blank sheet of paper the five projects they viewed as most important for the FASB to address. ${ }^{9}$ Results of the annual FASAC Survey are tabulated and presented together with council members' comments in a document entitled "Summary of Responses to the FASAC Annual Survey," which is distributed to Board members and discussed at a subsequent meeting of the FASB.$^{10}$ Data from FASAC Surveys provides quantitative, objective and contemporaneous data from which to estimate the otherwise archivally opaque interaction between the FASB and it's constituency across time. Given FASAC's mandate, composition and outreach efforts, these data constitute a meaningful proxy for the broader constituent lobbying environment surrounding the FASB's agenda decision.

\subsection{Hypothesis development}

\subsubsection{Average constituent preferences and FASB agenda decisions}

The general proposition that regulators attempt to optimally balance the demands of competing constituents is well established in both the economics and political science literatures (Becker 1983, Grossman and Helpman 2002), but as discussed in the preceding section, the precise mechanism for balancing these demands is difficult to specify ex-ante. Cognizant of the

\footnotetext{
${ }^{9}$ The 2002 shift in survey structure was intended to better solicit "the accounting and financial reporting issues that were the most challenging," in an environment characterized by "uncertainty and transition." (FASAC 2002/2003)

${ }^{10}$ Appendix A provides illustrative excerpts from the 1998 and 2002 FASAC Surveys and Summaries of Responses.
} 
competing economic consequences and political implications of its standards, it is easy to imagine the FASB might attempt to maximize its utility by undertaking only those agenda projects for which it expects criticism will be minimal relative to the accolades it anticipates across its entire constituency (Wilson 1980). Pragmatically however, lacking credible information about the preferences its broad constituency, the FASB is reliant on the subset of information provided by those constituents willing to engage in its due process. Optimizing its decisions, then, will involve some subjective determination as to the appropriate weighting of this information.

The consultative role and representative composition of FASAC suggest that its existence may have been institutionalized to facilitate such optimization. If this is the case, one might conjecture that the simple average of FASAC member preferences, readily available to Board members in the Summary of Responses to the FASAC Survey, may constitute a pragmatic weighting heuristic for FASB agenda decisions. Lending weight to this supposition, Figure 1 reveals that although variation exists, the general proportion of auditors, preparers, and financial representatives appointed to the FASAC has remained relatively stable over time. ${ }^{11}$ Between 1982 and 2006, the FASAC averaged 33 members, proportionally distributed as follows: $23 \%$ auditors, 30\% preparers, 29\% financial, and 18\% others. Accordingly, my first hypothesis, stated in terms of the alternative, is as follows.

[H1] The probability that a topic will be added to the FASB's technical agenda is, ceteris paribus, increasing in the average project priority FASAC members assign to that topic.

Although H1 intuitively resonates, establishing this baseline result is a non-trivial first step in my analysis; no systematic evidence currently exists on constituent preferences at the agenda setting stage. Furthermore, although economic theory postulates the necessity of the

\footnotetext{
${ }^{11}$ Members of FASAC are classified as auditors, preparers, financial and other, as detailed in Section 3.3.2.
} 
Board appearing responsive, this need not translate into agenda decision outcomes. Board members may use FASAC input opportunistically, citing constituent preferences for support when they naturally align with the Board's predetermined selections, and citing its independent jurisdiction or invoking the symbolic overriding public-interest of users (e.g., Young 2006) when they do not. Stated otherwise, it is possible that constituent preferences are manifest in the Board's agenda only to the extent that they correlate positively with FASB members' ex-ante preferences. By including a control for FASB member ex-ante preferences (see Section 3.4.1) H1 is designed to test for agenda responsiveness in fact rather than just in appearance.

\subsubsection{Differential influence of auditors, preparers, and financial constituents}

Although the average preference expressed by FASAC may constitute a useful starting point for the FASB to internalize constituent preferences in its agenda decision, it likely does not fully capture the host of political and institutional factors likely to shape the balance of constituent influence. Indeed, while an empirical test of $\mathrm{H} 1$ can provide strong evidence as to how the FASB internalizes general consensus opinions, it offers little insight as to how disagreements amongst constituents may be systematically resolved. In particular economic theory provides at least three potential forces which may be relevant to this setting.

\section{Informational Dependencies}

In deliberating, the FASB is only partially informed as to the economic and political consequences of policy decisions and, as such, are reliant on outside constituents to provide decision relevant information (e.g. Austen-Smith 1993). The information provision by constituents, however, is expected to be strategically self-serving and the extent to which it is weighted in FASB agenda decisions will likely hinge on the perceived incentive-alignment between the interests of the FASB and the lobbying constituent (Crawford and Sobel 1982, 
Farrell 1995). Ex-ante the FASB's ideological espousement of investors' and creditors' needs as paramount suggests a potentially strong alignment between the demands of financial constituents and FASB agenda decisions; financial constituents by construction are best suited to advise the FASB on decision relevance to users. However, these same constituents are often themselves preparers or may have perverse incentives to preserve personal information advantages and may not always lobby for greater accounting transparency. In similar vein, the FASB's might rely on auditors, as technical accounting experts to provide insight to the pervasiveness of a problem, and technical feasibility of alternative solutions but will be wary of auditors incentives to lobbying strategically in favor of their clients, or to maximize their own audit fees. Finally, preparers possess valuable information regarding the potential congruence between accounting practices and underlying firm economics, practical implementation issues and economic consequences, but may lack credibility due to perceived incentives to avoid costs or to mislead providers of capital. Accordingly, the weighting of constituent preferences in FASB decisions is likely to reflect prevailing perceptions of each group's credibility and may vary over time.

\section{Financial Dependencies}

Hall and Wayman (1990) argue that the impact of monetary contributions is most likely to manifest in influence at the agenda-setting stage of regulation. Although FASB members are not subject to election and therefore cannot be bought with campaign contributions, an average of $39 \%$ of the FASB's operational funding prior to 2002 came from voluntary contributions made by auditors (in particular the Big $\mathrm{N}$ firms) and, to a lesser extent corporate preparers. If this financial dependency resulted in preferential access to policy makers (e.g. Aranson and Hinich 1979, Austen-Smith 1995), or direct influence over policy outcomes (e.g. Austen-Smith 
1987, Grossman and Helpman 2002) the preferences of auditors and preparers may manifest more prominently in FASB agenda decisions prior to the 2002 change in funding structure.

\section{Institutional Dependencies}

From its foundation, the FASB has afforded preferential institutional status to auditors in the standard setting process. Five of the original 9 FAF council members (who are jointly responsible for selecting FASB, FASAC and subsequent FAF members) were appointed by the AICPA. Moreover, the AICPA retained standard setting authority within GAAP hierarchy; Industry and Accounting Guides, Statements of Position and ACSEC practice bulletins are designated as authoritative guidance. Likewise, auditors have historically enjoyed greater representation on the FASB, averaging 3 seats compared to 1-2 for preparers and $0-1$ for financial representatives, and until 2010 all FASB Chairmen were former auditors. Such institutional prominence might manifest in systematic deference to auditors preferences.

On the other hand, the FASB is institutionally beholden to the SEC and Congress, each of whom has effectual veto power over FASB agenda decisions. ${ }^{12}$ Financial constituents may garner significant influence over the FASB's agenda by transference of the SEC investor protection mandate. Moreover, Allen and Ramanna (2013) document a significant upward trend in the institutional presence of financial constituents on the FASB itself over time. Additionally, preparers have proven adept in lobbying Congress to alter regulatory outcomes using economic consequences arguments in later stages of standard setting (Zeff 1978, Ramanna 2008). At the agenda setting stage, however, considerable uncertainty exists regarding the eventual accounting solution which may weaken preparers' ability to successfully lobby. Thus, influence at the

\footnotetext{
${ }^{12}$ In practice, use of such veto power is rare, potentially reflecting the FASB's reluctance in equilibrium to undertake projects where the perceived threat of regulatory intervention is high.
} 
agenda setting stage is not necessarily predicted by evidence of regulatory success at later stages, and is an open empirical question.

\section{Aggregate Influence:}

The FASB assertion of "balance" in standard setting suggests that the distinct preferences of each of the FASB's constituents should weigh significantly in its agenda decisions. On the other hand, as described above, informational, financial and institutional dependencies between the FASB and its constituents may create potential biases over time. Accordingly, hypothesis two is somewhat exploratory in nature and is constructed to provide evidence as to whether constituent influence appears to be broadly dispersed or is concentrated in the hands of only a few key players. $\mathrm{H} 2$ is stated formally in three parts below in terms of the alternatives.

[H2] The probability that a topic will be added to the FASB's technical agenda is increasing in the average project priority which FASAC members representing [a] auditor, [b] financial, and [c] preparer constituencies assign to that topic.

Evidence in favor of all parts of H2 would be consistent with the FASB's assertion of "balance" in standard setting, whereas evidence in favor of only one proposition might suggest a regulatory outcome which is partial to, or at the extreme captured by, certain constituencies.

Although causal analysis is not feasible due to the constraints of a split sample, ex-ante, 1982-2001 and 2002-2006 political dynamics are expected to differ. Around 2002, in the wake of public scrutiny and regulatory reforms motivated by a sequence of large accounting scandals, auditors and preparers credibility was significantly damaged. Additionally, responding to concerns regarding conflicts of interest the Sarbanes Oxley Act $§ 109$ severed the financial ties between the FASB and Big $\mathrm{N}$ auditors by establishing a mandatory fee system to fund the FASB's operations. Finally, under intense scrutiny from both the SEC and Congress, the FASB voluntarily undertook structural initiatives intended to increase the structural influence of financial users including establishment of the Users Advisory Council (UAC), Investors 
Technical Advisory Committee (ITAC), and Investors Task Force (ITF). ${ }^{13}$ To the extent these changes significantly altered the political dynamics of FASB agenda decisions; I am more likely to find evidence in favor of auditor and preparer influence in my 1982-2001 sample and of financial constituents in my 2002-2006 sample.

\subsubsection{Influence of large constituents}

Influencing the agenda likely necessitates the mobilization of resources both to become informed about agenda issues and to successfully lobby for preferred positions (Becker 1983, Austen-Smith 1987; 1993; 1995). It therefore intuitively follows that in the presence of intraconstituent disagreement large auditor, preparer and financial firms, leveraging superior financial resources, may have greater influence in the FASB's agenda selections than do their smaller counterparts. Conditional on finding significance of constituent preferences in $\mathrm{H} 2$, hypothesis three is stated in three parts below in terms of the alternatives.

[H3] The probability that a topic will be added to the FASB's technical agenda is increasing in the average project priority FASAC members representing large [a] auditor, [b] financial, and [c] preparer constituencies assign to that topic, but is not significantly affected by the preferences of small constituents.

Several factors may temper this prediction. First, perhaps in response to large firms' perceived advantage with regard to influencing standards, the SEC's (and by transference, the FASB's) fairness objective aims to protect small and/or unsophisticated financial statement users. The FASB's explicitly stated objective of issuing standards that improve decision usefulness may be similarly intended to reduce information asymmetries for small financial constituents that are disadvantaged relative to larger users. In addition, two of the FASB's founding organizations, the American Institute of Certified Public Accountants (AICPA) and

\footnotetext{
${ }^{13}$ The UAC includes representatives from individual and institutional investors, equity and debt analysts, lenders and credit rating agencies, the ITAC from the investment community with primary career focus on accounting and financial reporting matters, and the ITF from large institutional asset managers.
} 
Securities Industry Association, represent the interests of small auditors and small financial investors, respectively, and may provide effective channels of influence for these two groups.

The distinction between large and small constituent preferences is important to the FASB's balancing objective. Small preparers, bearing disproportionately high implementation costs relative to their larger counterparts, may have a stronger preference for the status quo (Watts and Zimmerman 1978). Likewise small auditors, having higher relative learning costs, may be less likely than large accounting firms to favor accounting change (Puro 1984). Finally, small investors will tend to advocate for greater mandated disclosure than their informationally advantaged large financial counterparts, which may have strategic incentives to advocate for uninformative financial reports (Dye and Sridhar 2008). Lev (1988) suggests that the FASB should prioritize the needs of small investors over those of large financial institutions to avoid the adverse capital market consequences of information inequity.

\section{Sample construction and variable measurement}

\subsection{Sample construction: FASAC Survey on potential projects}

Table 1 summarizes the relevant details of FASAC Survey content and participation between 1982 and 2006. FASAC members were surveyed about 242 potential agenda projects between 1982 and 2001. From 2002 to 2006, 81 potential projects were listed as being in the "Top 5" by FASAC or FASB members. These 323 projects constitute the primary sample for my analysis. Average participation in the survey is $79 \%$ and $82 \%$ for the $1982-2001$ and $2002-2006$

periods, respectively, which translates into 6,221 unique Likert-scale project evaluations from 1982 to 2001, and 2,159 unique open-ended binary evaluations (Top 5 or not) from 2002 to 2006. From 1998 to 2006, FASB members were also included in the FASAC Survey, and responded with a participation rate of $100 \%$. 
Copies of individual survey responses are not part of the public record and are protected by the terms of historical disclosure agreements with survey participants. Data on constituent preferences is obtained from annually published "Summaries of Responses to the FASAC Survey", on file in the FAF Public Archive in Norwalk, Connecticut. ${ }^{14}$ From 2002 to 2006, individual level response data is reported in entirety in the Summaries. From 1982 to 2001, however, individual level data is unpublished for two years (1984 and 2001), and in the remaining sample is presented only for those participants who provided written comments in addition to Likert-score ratings. ${ }^{15}$ As illustrated in Table $1,46 \%(2,926)$ of individual project evaluations are visible under this restriction.

To understand the effect of missing data on my analysis, Table 2 compares the available 2,926 individual responses by constituent group to the overall composition of FASAC. The distribution of comments across my sample is similar to the distribution of total FASAC membership alleviating concern that the subsample composition differs systematically from the actual distribution of responses. Additionally, I manually compute the simple average of FASAC member Likert-ratings for which I have individual level data (commenting_fasac) and compare it to the true average Likert-rating across all respondents as reported in the Summary of Responses (average_fasac). The correlation between commenting_fasac and average_fasac is 0.85 .

\subsection{Dependent variable: FASB agenda decision}

The dependent variable for my analysis is a binary variable (agenda_add $t_{t+1}$ ) that takes a value of 1 for each potential agenda project from the year $t$ FASAC Survey that was added to the

\footnotetext{
${ }^{14}$ No FASAC survey was conducted in 1988. The 1996 and 1997 Surveys did not address potential projects due to an "already full agenda." No projects were added to the FASB's agenda in 1997, and in 1998 additions were limited to two "limited scope projects": "Technical Corrections" (SFAS 135) and "Motion Picture Films" (SFAS 139).

${ }^{15}$ The FASB was unable to provide an explanation for historical variation in the presentation of FASAC survey results.
} 
FASB's technical agenda prior to the publication date of the $t+1$ FASAC Survey. Information on the timing of new project additions is obtained from the FASB's "Technical Plan," published quarterly as part of the FASB Status Report (later renamed the FASB Report), available through the AICPA library at the University of Michigan.

\subsection{Independent variables: FASAC member preferences}

\subsubsection{Average FASAC preferences}

Average FASAC member project ratings (average_fasac) for the 242 projects in my 1982-2001 sample are reported in the respective Summaries of Responses. Standardization of average_fasac to account for variation in Likert-scale granularity is achieved as follows.

$$
\text { fasac_pref }_{i t}=1-\frac{\text { average }_{-} \text {fasac }_{i t}-1}{\operatorname{LSmax}_{t}-1}(E q 1)
$$

In Eq. (1), average_fasac $i t$ is the un-scaled average rating assigned to project $i$ in year $t$. $L \operatorname{Smax}_{t}$ is the maximum Likert-scale value used in year $t$ and takes values $\{2,3,5,8\}$ across my sample, as shown in Table $1 .{ }^{16}$ In the original Surveys, higher Likert-scores indicate lower priority; for ease of interpretation Eq. (1) transforms average_fasac it $_{\text {s }}$ such that fasac_pref $f_{i t}$ is increasing in the strength of average FASAC preference for a project, and is bounded $[0,1]$. From 2002 to 2006, survey respondents mention 81 potential projects as being of "Top 5" priority. Average FASAC priority ( fasac_pref $_{i t}$ ) is calculated manually from the Summaries of Responses as the proportion of respondents that list project $i$ in their "Top 5 " for year $t$.

\footnotetext{
${ }^{16}$ Because my analyses regress FASB agenda decisions on mean constituent preferences rather than individual responses, the noise introduced by rescaling is unlikely to systematically bias results. Untabulated analyses on a subset of years (1990-1995) for which granularity of responses is constant suggest robustness to this choice.
} 


\subsubsection{Average FASAC preference by constituent type}

Data on FASAC members' professional affiliations is obtained from FAF annual reports (available from the FAF public archive) and manually merged with FASAC Survey Data. Using the taxonomy outlined in the 1988 FAF annual report, FASAC members are classified as belonging to one of four mutually exclusive groups as follows. auditor includes members employed in the public accounting profession. financial includes members employed in the banking, insurance, or securities industry. preparer includes members of industry not classified as auditor or financial. other includes academics, attorneys, non-profit, and government representatives.

Analogous to the construction of aggregate FASAC member preferences (fasac_prefit), individual FASAC member preferences for the 1982-2001 sample are rescaled to a range of [0, 1] which is increasing in members' reported priority for project addition. Re-scaled individual preferences are then averaged across each constituent group to generate four variables: aud_pref $_{i t}, f i n \_p r e f_{i t}$, prep_pref $f_{i t}$ and other_pref $f_{i t}$ which reflect average auditor, financial, preparer, and other FASAC member preferences, respectively, for project $i$ in year $t$. For 20022006, aud_pref $f_{i t}$, fin_pref $f_{i t}$, prep_pref $_{i t}$ and other_pref $f_{i t}$ are computed as the proportion of each constituency who listed a project $i$ in her top 5 in year $t$. As discussed in Section 3.1 data on individual preferences are unavailable for 1984 and 2001 (26 projects) and an additional 30 projects are excluded due to missing individual level data for at least one constituent group. After exclusions, 186 (81) potential projects remain from 1982 to 2001 (2002 to 2006) for testing H2.

\subsubsection{Large versus small constituents}

FASAC members classified as auditor, financial, and preparer are further segregated as representing large and small institutions as follows. big_aud is constructed as the average project 
priority of members employed by Big $\mathrm{N}$ audit firms (Big 8, 6, 5, and 4, respectively, over time). big_fin is constructed as the average project priority of members employed by commercial banks, investment management firms, investment banks, insurance companies, or private equity firms with total assets greater than or equal to the total assets of the $20^{\text {th }}$ largest bank holding company (BHC), as reported in the Bank Regulatory database, for each year in my sample. The Big 2 rating agencies are also classified as big fin. Appendix B lists the total asset cutoff values used for each year as well as the member organizations represented on FASAC that fall above and below these cutoffs. ${ }^{17}$ big_prep is constructed as the average project priority of members employed by Fortune 500 companies. little_aud, little_fin, and little_prep are constructed as the complements of big_aud, big_fin, and big_prep, respectively. ${ }^{18}$

From the sample of 186 (81) projects available for testing H2, an additional 100 (0) projects, for which no individual data on the preferences of at least one disaggregated constituent group is visible in the Summary of Responses, must be excluded from my sample. After data limitations, 94 (81) potential projects remain from 1982 to 2001 (2002 to 2006) for testing H3.

\subsection{Control variables}

\subsubsection{FASB member ex-ante project priorities}

From 1998 to 2006, the FASAC Survey polled FASB members directly and their preferences are reported in the Summaries of Responses. Accordingly, for my 2002-2006 sample, FASB member priorities can be controlled for explicitly. Analogous to the construction

\footnotetext{
${ }^{17}$ There is no standard definition of "big finance" in the literature and, ex-ante, any separating criteria is necessarily arbitrary. Ex-post however, a clear distinction is apparent between large and small firms for each finance industry represented in my sample and is captured appropriately by the total assets cutoff employed herein. See Appendix B. ${ }^{18}$ little_aud includes the AICPA member representative, and little_fin includes the SIFMA member representative.
} 
of fasac_pref for this period (see Eq. (1)), fasb_pref is constructed as the proportion of FASB members that rated project $i$ as a "Top 5" priority in year $t$.

For my 1982-2001 sample, I construct a binary variable (fasb_proxy) based on a manual review of FASB Status reports for mention of potential agenda projects. Quarterly, the FASB provides a partial listing of "other issues" it has "received requests to consider" for its future agenda. The listing is "not intended to be comprehensive"; in 1988, for example, the FASB screened nearly 100 potential projects (FAF 1988), but only eight are mentioned in that year's Status Reports. Accordingly, I interpret the choice of issues mentioned as an ex-ante manifestation of which projects were, at an early stage, viewed by the FASB as stronger potential candidates for its agenda. Conversations with prior Board members and staff confirm the reasonableness of this assumption. fasb_proxy $y_{i t}$ is coded 1 for each potential project $i$ mentioned in the four quarterly Status Reports preceding the year $t$ FASAC Survey.

To judge the validity of fasb_proxy I compare it to the explicit measures of FASB member preferences available in the Summaries of Responses from 1998 to 2006. The correlation between fasb_proxy (binary) and fasb_pref (continuous) is 0.47 (p-value 0.004) for 1998 to 2001 and 0.36 (p-value 0.001 ) for 2002 to 2006. Additionally, to ensure that my construct is meaningful but not mechanical, I examine the univariate relationship between fasb_proxy and my dependent variable (agenda_add). The odds of agenda inclusion increase by $24 \%$ (p-value <.001) when fasb_proxy is equal to $1 ; 7(29 \%)$ of 24 projects for which fasb_proxy is equal to 1 are subsequently added to the Board's agenda versus only 11(5\%) of 218 projects when fasb_proxy is equal to 0 . 


\subsubsection{SEC project priorities}

The SEC holds statutory standard-setting authority from Congress, but has voluntarily delegated responsibility for the promulgation of accounting standards to the FASB. Notwithstanding, the SEC retains close review liaison. The SEC Chief Accountant regularly attends FASAC meetings and may suggest topics for inclusion on the FASB's agenda. During his ten years as chairman of the FASB, Dennis Beresford noted that SEC suggestions were most often at the level of practice problems, which were handled by the EITF; however, in the "relatively rare" case the SEC became involved with its technical agenda, the FASB considered it "very seriously." 19 To control for this potential influence, I construct a proxy for SEC preferences (sec_proxy) based on a review of all quarterly FASAC meeting minutes (during which the SEC Chief Accountant makes a presentation) and the SEC Annual Reports' “Accounting Matters" section. ${ }^{20}$ sec_proxy is coded 1 for any potential project discussed favorably by the SEC during the 12 months that directly precede or follow the FASAC annual survey.

\subsubsection{International accounting convergence}

In 1991, the FASB committed to actively consider International Accounting Standards in the development of its own projects, and since 2002 has actively pursued the objective of convergence. Accordingly, FASB project selection may be influenced by the concurrent agenda of the International Accounting Standards Board (IASB, formerly IASC), which may itself be influenced differentially by the preferences of its broad constituent base. To control for this possibility, I construct a dummy variable $\left(i a s b_{i t}\right)$ that is set equal to one if there exists a project to

\footnotetext{
${ }^{19}$ Personal phone interview with Dennis Beresford on 7/26/2012 about his experiences as chairman of the FASB from 1987-1997

${ }^{20}$ FASAC meeting minutes are available through the FAF public archives, SEC annual reports online at sec.gov.
} 
address issue $i$ on the IASB's (IASC's) agenda during the 12 months preceding or following the year $t$ FASAC Survey or if issue $\mathrm{i}$ is included in a previously issued memorandum of understanding between the FASB and IASB. ${ }^{21}$

\section{Descriptive statistics and multivariate research design}

\subsection{Descriptive statistics}

Table 3, Panel A provides summary statistics for my dependent variable. Eighteen (7.4\%) of the 242 potential projects in my 1982-2001 sample, and seven (8.6\%) of the 81 potential projects in my 2002-2006 sample, are subsequently added to the board's agenda. These low proportions are consistent with the FASB's assertion that they screen "far more [proposed agenda topics] than we can possibly accommodate" (FAF 1988).

Table 3, Panel B provides summary statistics for my independent variables. From 1982 to 2001, the mean values for fasac_pref, aud_pref, user_pref, prep_pref, big_aud, little_aud, big_fin, little_fin, big_prep, and little_prep are in the range of $0.34-0.55$, suggesting that the board's primary constituents favor adding just under half of the projects proposed on the FASAC's annual survey. Lower average priority is assigned to potential projects by preparers than by any other constituency (t-test p-values <0.01), consistent with the argument that preparers are more likely to favor the status quo. Panel $\mathrm{B}$ also reveals that Big $\mathrm{N}$ auditors (big_aud) and financial constituents, regardless of size (big_fin and little_fin), give more favorable assessments to potential projects than do other constituent groups. This may reflect exante Big $\mathrm{N}$ auditor and finance industry influence on the selection of potential projects included

\footnotetext{
${ }^{21}$ Information on the IASB's (IASC's) technical agenda prior to 2001 is obtained from Camfferman and Zeff (2007) and post 2001 compiled from the IASB Updates available through ifrs.org.
} 
on the FASAC Survey, or simply that, on average, these groups view any change in accounting standards more favorably.

Pearson correlations between the explanatory variables in Table 3, Panel B are shown in Table 3, Panel C. From 1982 to 2001, correlations between constituent groups' priorities are generally low, consistent with a high degree of variation in constituent incentives regarding financial reporting standards. The highest observed correlations are between big_prep and little_prep (.65); and big_aud and little_aud (.43). Interestingly the corre1lation between big_fin and little fin is low (.14) consistent with the argument the preference of large financial firms may not align with the needs of small users (Dye and Sridhar 2008, Lev 1998). Correlations between all explanatory variables are higher in the 2002-2006 sample than in the 1982-2001 sample. In particular Table 3, Panel $\mathrm{C}$ reveals a particularly high correlation (.65) between preparer and financial industry preferences in this period which appears largely driven by the alignment of large financial firms (big_fin) with preparers (big_prep and little_prep). ${ }^{22}$

\subsection{Multivariate research design}

Although there are no formal constraints on the number of projects the FASB can add to its technical agenda, time and resource constraints impose practical limits on the number of potential projects that can be undertaken simultaneously. Thus, agenda decisions in any given year $t$ may be jointly determined. To address intra-cluster correlation I estimate the conditional probability of $y_{i t}$ on other outcomes from the same cluster (i.e., the set of $y_{j t}$ ) using a conditional fixed effects model (e.g. Pendergast et al. 1996).

The formal specifications for my regressions are given by Equations (4)-(6) below:

\footnotetext{
${ }^{22}$ To assess the impact of high correlations on multivariate regression analysis, variance inflation factors (VIFs) were computed for all regressions. Without exception VIF's are $<10$, alleviating multicollinearity concerns.
} 


$$
\begin{aligned}
& \operatorname{logit}\left[\operatorname{Pr}\left(Y=\text { agenda_add } d_{i t+1}=1\right) \mid X_{i t}, W_{i t}, F E_{t}\right]=\beta_{0 t}\left(F E_{t}\right)+\beta_{1 t} X_{i t},+\gamma_{1, t} W_{i t} \text {; where }
\end{aligned}
$$

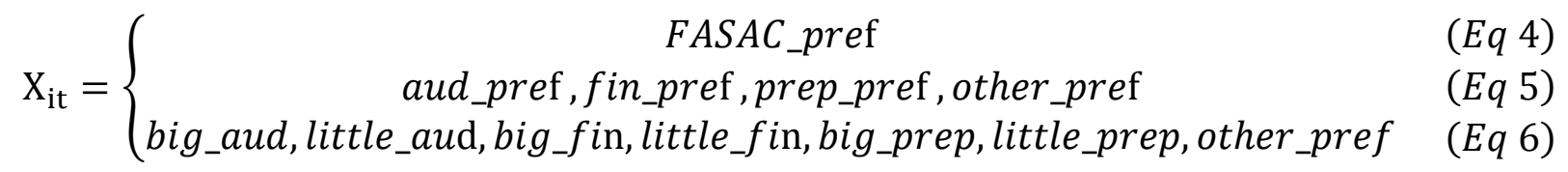

$$
\begin{aligned}
& W_{i t}=\left\{f a s b \_p r e f \text { or } f a s b \_p r o x y, \text { sec_proxy,ias } b\right\}, F E_{t}=\text { Year fixed effect }
\end{aligned}
$$

In Eq. (4)-(6), $i$ is a potential project included on the year $t$ annual FASAC Survey and $\beta_{0 t}$ and $\beta_{1 t}$ are the mean intercept and slope parameters, respectively, for cluster $t$. Standard errors are clustered by year. Results are reported both with and without controls for FASB and SEC preferences $\left(W_{i t}\right)$. Conditional fixed-effect estimation requires variation in the outcome variable within each cluster $(t)$; years in which no potential projects from the FASAC Survey are subsequently added to the Board's agenda will be excluded from estimation of model parameters resulting in diminished sample size. ${ }^{23}$ For comparison all results are presented using both the full sample (unconditional logit) and the conditional sample (fixed effects logit), however, more weight should be placed on the results of conditional specification. ${ }^{24}$

\section{Results}

\subsection{Influence of aggregate FASAC preference on the FASB's agenda}

Table 4, Panels A and B report regression results on the responsiveness of FASB agenda decisions to average FASAC member preferences for my 1982-2001 and 2002-2006 samples, respectively. Of the six columns in each of the panels in Table 4, columns (1), (3), and (5) are

\footnotetext{
${ }^{23}$ No potential projects from the FASAC annual surveys for 1983, 1984, 1986, 1989, 1990, 1992, 1998, and 2006 were added to the FASB's technical agenda during the following year.

${ }^{24}$ An alternative to address intra-cluster correlation is to use a random effects model which preserves data from clusters without dependent variable variation by imposing the assumption of orthogonality between the cluster parameter and the explanatory variables. In my setting, there are numerous omitted year trend variables likely to violate this assumption including the FASB's annual budget, the number, scope, and estimated horizon of projects currently on the agenda, and public sentiment regarding the issue of "standards overload." For this reason, a conditional fixed effects model is more appropriate; however all results are robust to a random effects specification.
} 
estimated using a simple logit model with year-cluster robust standard errors, columns (2), (4), and (6) using a conditional year-fixed effect logit model. For both estimation models, regressions are presented first without controls, then with only FASB controls, and lastly with FASB, SEC and IASB controls. Simple logit coefficients are estimated on the full sample of 242 (81) potential projects from the 1982-2001 (2002-2006) FASAC Surveys. The sample size is reduced to 143 (67) for conditional fixed effect estimation.

In aggregate, the results from Table 4, Panels A and B provide support for the hypothesis that FASB agenda decisions are responsive to constituent preferences, as proxied by FASAC member responses. Across all model specifications and both samples, FASAC priority (fasac_pref) is significant with and without the inclusion of controls. As expected, fasb_proxy is also significant across all specifications in the 1982-2001 regressions as is fasb_pref using 20022006 data; sec_proxy and iasb are significant from 1982-2001, but not from 2002-2006. Converting the coefficients from Panel A (B) column (6) to odds ratios indicates that a change of one standard deviation, $0.16(0.11)$, in average FASAC priority increases the likelihood of a project's addition to the subsequent year's agenda by a factor of 1.66 (3.21). Collectively, the results from Table 4, suggest that constituent preferences are an important input to FASB agenda decisions, incremental to FASB members ex-ante ideological preferences.

\subsection{Influence of auditor, financial, and preparer preferences on the FASB's agenda}

Table 5, Panels A and B present regression results on the responsiveness of FASB agenda decisions to auditor, financial, preparer, and other FASAC member preferences for the 19822001 and 2002-2006 periods, respectively. Owing to individual level data restrictions discussed in Section 3.1, sample size is reduced to 186 for simple logit and 111 for conditional logit estimation in Panel A. Table 5 is otherwise identical in all respects to Table 4. 
Table 5, Panel A provides evidence that from 1982 to 2001, both auditor and financial constituent preferences had significant influence on the FASB's agenda; aud_pref and fin_pref are positive and statistically significant across all specifications. Consistent with auditors having financial and institutional advantages during this period, auditor preferences appear more impactful than financial preferences. Conversion of the coefficients in Table 4, column (6) to odds ratios suggests that a project's probability of agenda inclusion is increased by $87 \%$ by a one standard deviation (0.16) increase in auditor priority, but only by $41 \%$ by an equivalent increase in financial representatives' priority; the difference is significant ( $\mathrm{p}$-value $=0.025$ ).

Table 5, Panel B presents results of the regression analysis from 2002 to 2006. In contrast to the results reported in Panel A, there is no evidence to suggest that average auditor priority (aud_pref) is related to the FASB's agenda decisions during this period. Instead, financial constituents' preferences (fin_pref) alone appear significant across all specifications consistent with the temporal rise in financial sector influence documented in Allen and Ramanna (2013). Computing the odds ratios for column (6) suggests that a one standard deviation increase in the proportion of financial representatives who rank a project in their top 5 increases the likelihood of agenda admission by a factor of 9.8. Notably, I find no evidence of preparer (prep_pref) influence on the FASB's selection of agenda projects in either Panel A or Panel B, in contrast with research on later stages of standard setting that has documented significant preparer influence.

\subsection{Influence of large and small constituent preferences on the FASB's agenda}

Table 6, Panel A and Panel B report for the 1982-2001 and 2002-2006 samples, respectively, the results of regression tests on constituent preferences disaggregated into "large" and "small" institutions (big_aud and little_aud, big_fin and little_fin, and big_prep and 
little_prep). Based on the visibility of individual level data, sample size is reduced to 94 for simple logit and 52 for conditional logit estimation in the 1982-2001 sample. Table 6 is otherwise identical to Table 5 .

As hypothesized, Table 6, Panel A suggests that the significant coefficient on aud_pref in Table 5, Panel A is attributable to the influence of Big $\mathrm{N}$ audit firms; big_aud is significant and little_aud insignificant across all regression specifications. Odds ratios suggest that a one standard deviation increase in average Big $\mathrm{N}$ auditor preferences (big_aud) increases the likelihood of agenda addition by a factor of 2.1. When disaggregated, the significant coefficient on financial constituents' preferences observed in Table 5 is present for neither big_fin nor little_fin, making it difficult to assess conclusively what impact, if any, financial constituents had on the FASB's agenda during this period. As in Table 5, preparer priorities (big_prep and little_prep) are not significant.

Table 6, Panel B shows the significant fin_pref estimate for 2002-2006, reported in Table 5, Panel B, may be driven by both the influence of large and small financial constituents, inconsistent with $\mathrm{H} 3[\mathrm{~b}]$. The estimates for little_fin and big_fin are of similar magnitude and are significant most specifications. This result is surprising when the financial and political advantages of large financial institutions are considered, but may be consistent with the FASB's fairness objective and with SEC emphasis on the needs of smaller investors.

Taken together, the results of Tables 5 and 6 are consistent with the premise that regulatory and institutional changes accompanying the accounting scandals of the early 2000s substantially impacted the relationship between the FASB's agenda decisions and constituent preferences. Specifically, prior to 2002, consistent with auditors having institutionalized structural and financial advantages during this period, Big $\mathrm{N}$ audit firms appear to have dominant 
influence over FASB agenda decisions. Post 2002, in the absence of these advantages auditor influence is attenuated and instead financial constituents appear to command the prevailing advisory role. If financial constituents are taken as synonymous with users this findings is consistent with the stated intent of regulatory and institutional initiatives to bolster the primacy of user interests in standard setting. On the other hand, if financial constituents lobby as preparers or strategically as informationally advantaged market participants (e.g. Dye and Sridhar 2008), the ascendency of financial firm preferences may not necessarily benefit users.

\section{Additional Tests}

\subsection{Financial firm expertise}

The informational expertise of financial constituents is likely to be particularly relevant to FASB decisions when the agenda project being contemplated is financially topical. Thus, controlling for the underlying subject matter of agenda projects may be critical to ascertaining the true influence of financial constituents, and might also help explain the increasing influence of financial constituents if the FASB contemplated more financial projects post 2002. To investigate this possibility, I create a dummy variable (fin_issue) to capture proposed agenda topics dealing with debt, investments, financial instruments, leasing or financial institutions. Summary statistics reveal that the proportion of proposed agenda projects pertaining to financial transactions is not substantially different across my two samples; $24 \%$ and $21 \%$ of proposed agenda topics address financial transactions in my 1982 to 2001 and 2002 to 2006 samples, respectively. Thus, the subject mix of proposed projects is unlikely to explain the ascendancy of financial firm influence over time. Table 7 presents the results of re-estimating columns (6) of Table 5 panels $\mathrm{A}$ and $\mathrm{B}$ after including controls fin_issue and an interaction term

(fin_pref*fin_issue). As seen in Table 7, Column (1) for 1982 to 2001 sample, fin_issue and 
fin_pref*fin_issue do not load significant. By contrast, for the 2002 to 2006 sample (Column 2) fin_pref*fin_issue is positive and highly significant as is fin_pref and suggesting that financial constituents' influence is accentuated for, but not limited to financial agenda proposals. Thus, while there is evidence that financial constituents influence on FASB agenda decisions varies predictably with subject matter expertise, this expertise appears to be a relevant factor only post2002. From 1982-2001, auditor preferences alone appear significant, consistent with the results in Tables 5 and 6.

\subsection{Preparer preference heterogeneity}

For any potential project, only a subset of preparers may be affected (Leftwich 1995). Accordingly, an alternative explanation for the lack of significance of preparer preferences across my regressions is that aggregated preparer preferences are a poor proxy for the political pressure exerted by a small subset of influential preparers on any given issue. Given the limited visibility of political maneuvering at the agenda setting stage, my analysis cannot comprehensively address this concern; my vantage is limited to the preferences of those preparers represented on the FASAC. However, some evidence can be obtained by re-estimating Table 5 regressions using the priority ratings of the Financial Executives Institute (FEI) representative in place of average preparer preference. The FEI is one of the FASB's sponsoring organizations and has been active across the FASB's history in lobbying for preparer interests (e.g., Van Riper 1994). FEI preferences are available for a subsample of 117 (81) projects from 1982 to 2001 (2002 to 2006). Untabulated results obtained from these subsamples are consistent with those reported in Table 5; the coefficient on FEI remains insignificant across all specifications. 


\subsection{Media influence}

Although the financial press generally shows little interest in the FASB's activities, the media has in specific instances actively engaged in discussion of a proposed accounting standard (e.g., stock options, pensions). In such instances, heightened media coverage may increase public policy pressure and influence regulators' decisions. If this is the case, and if media attention is systematically correlated with the preferences of a particular constituent group, failure to control for media pressure could lead to biased inferences in my primary analysis. Accordingly, I construct a control variable, media_coverage $i t$, which is equal to the raw number of articles in the Wall Street Journal and Financial Times during the 12 months preceding each FASAC Survey returned by a Factiva search for the key words FASB (or Financial Accounting Standards Board) plus a set of terms specific to each potential topic $i$, scaled by the total number of articles published over the same period. When included in regression analysis, media_coverage does not load significant, nor does its inclusion substantively change the results reported in Tables 4-6.

\section{Conclusion}

Motivated by theoretical literature in economics and political science that suggests that determination of a regulatory agenda will have significant economic consequences for the regulated, I examine the significance of auditor, preparer, and financial constituent preferences in the determination of the FASB's technical agenda. Data on constituent preferences is obtained by leveraging a unique institutional feature of the FASB's agenda process, namely, formal consultation with an advisory council (FASAC) deliberately structured to represent the Board's broader constituency in "microcosm." Disaggregated survey data on FASAC member priority ratings from the FASAC Annual Survey for 323 potential projects considered between 1981 and 
2006 provide an opportunity to view the contemporaneous preferences of constituents that are otherwise archivally opaque at the agenda setting stage.

Key findings of my analysis are that constituent priorities are a significant determinant of the FASB's project selections, and that prior to 2002 influence is concentrated among only a few players, namely, "Big N" audit firms. Post 2002, potentially congruent with the intent of institutional changes designed to sever financial and institutional dependencies between the FASB and the large audit firms, as well to as increase participation of financial statement users in standard setting, Big $\mathrm{N}$ audit firms' priorities no longer appear to dominate the FASB's agenda decision. Instead, results from 2002 to 2006 suggest that the priorities of financial constituents weigh most heavily in agenda decisions. Contrary to prior literature that examines later stages of accounting standard setting, I find no evidence to suggest significant influence on the part of industrial preparers in agenda setting. Results of my analysis are robust to the inclusion of FASB member ex-ante agenda preferences, SEC project priorities, and year-fixed effects.

Broadly, this paper affords a preliminary look at an important dynamic in the political economy of US GAAP: the role of constituents in determining the FASB's technical agenda. Given the far-reaching economic impacts of financial accounting standards, the existence and power of forces that influence the selection of topics to be addressed have strong implications for the potential redistributive consequences of accounting standard setting. Although the limitations embedded in a secondary survey analysis do not enable me to establish conclusively whether the concentration of power in agenda setting shifted around 2002 as a direct result of the host of reforms designed to bolster the FASB's financial independence and/or increase financial constituent participation, my results highlight that a shift has occurred. Future research that 
disentangles the effects of various structural and regulatory reforms could shed light on which changes played the greatest role in effecting this change.

Future work in agenda setting can explore additional factors that might influence the FASB's agenda including the relative influence of public sentiment, accounting scandals, and economic cycles on the quantity and content of topics selected. Although aggregate FASAC preferences likely reflect contemporaneous economic and political forces, the direct effect of such forces merit separate investigation. To what extent, for example, do regulators over-react or under-react in the face of public criticism blaming undesirable economic consequences on poorly crafted accounting regulation? Investigating the influence of constituents after a topic has been added to the Board's agenda (where my study ends) but before a discussion memorandum or exposure draft is issued (where the majority of existing literature begins) constitutes another avenue for future research. Among the questions that merit exploration are how the universe of alternative solutions to an accounting problem are identified and vetted, and what forces influence the FASB's original position, project scope, and timeline. 


\section{References:}

Amershi, A. H., J. S. Demski, and M. A. Wolfson. 1982. Strategic behavior and regulation research in accounting. Journal of Accounting and Public Policy 1: 19-32.

Allen, A., Ramanna, K., 2013. Toward an understanding of the role of standard setters in standard setting. Journal of Accounting and Economics 55.1: 66-90

Allen, A., Ramanna, K., Roychowdhury, S., 2014. The auditing oligopoly and accounting standards lobbying: Working Paper.

Aranson, P.H., Hinich, M.J., 1979. Some aspects of the political economy of election campaign contribution laws. Public choice 34, 435-461.

Arrow, K.J., 1951. Social choice and individual values. New York: Wiley

Austen-Smith, D., 1987. Interest groups, campaign contributions, and probabilistic voting. Public choice 54, 123-139.

Austen-Smith, D., 1993. Information and influence: Lobbying for agendas and votes. American Journal of Political Science, 799-833.

Austen-Smith, D., 1995. Campaign contributions and access. American Political Science Review, 566-581.

Becker, G.S., 1983. A theory of competition among pressure groups for political influence. The Quarterly Journal of Economics 98, 371-400.

Beresford, D.R., 1993. Frustrations of a standard setter. Accounting Horizons 7(4), 70-76.

Bertomeu, J., Magee, R.P., 2011 From low-quality reporting to finacial crises: Politics of disclosure regulation along the economic cycle. Journal of Accounting and Economics 52(2-3), 209-227

Brown, P., 1981. A descriptive analysis of select input bases of the Financial Accounting Standards Board. Journal of Accounting Research 19(1), 232-246.

Brown, V.H., 1984. FASB viewpoints: Standard setting - a matter of balance. FASB Status Report 162, (Oct 25, 1984).

Camfferman, K., Zeff, S.A., 2007. Financial reporting and global capital markets: A history of the International Accounting Standards Committee, 1973-2000: Oxford University Press, USA.

Crawford, V.P., Sobel, J., 1982. Strategic information transmission. Econometrica: Journal of the Econometric Society, 1431-1451.

Cyert, R.M., Ijiri, Y., 1974. Problems of implementing the trueblood objectives report. Journal of Accounting Research 12, 29-42. 
Demski, J.S., 1973. The general impossibility of normative accounting standards. The Accounting Review 48, 718-723.

Dye, R.A., Sridhar, S.S., 2008. A positive theory of flexibility in accounting standards. Journal of Accounting and Economics 46, 312-333.

FAF, 1984. Financial Accounting Foundation: Annual Report. Stamford CT, p. 20.

FAF, 1986. Financial Acocunting Foundation: Annual Report. Stamford, CT.

FAF, 1988. Financial Accounting Foundation: Annual Report. Stamford, CT.

FAF, Oct 15, 1996. Meeting minutes, FASAC quarterly meeting with the FASB. Norwalk, CT.

Farrell, J., 1995. Talk is cheap. The American Economic Review, 186-190.

FASAC, 2002. Annual FASAC Survey: Priorities of the Financial Accounting Standards Board. Norwalk, CT: Financial Accounting Foundation.

FASAC, 2003. Annual FASAC Survey: Priorities of the Financial Accounting Standards Board. Norwalk, CT: Financial Accounting Foundation.

FASB, 1973. Rules of Procedure. Stamford, CT: Financial Accounting Foundation, p. 8.

FASB, 1978. Rules of Procedure: As amended through Jan 1, 1978. Stamford, CT: Financial Accounting Foundation.

FASB, 2007. Facts about FASB: Mission of the Financial Accounting Standards Board. Norwalk, CT: Financial Accounting Foundation.

FASB, 2013. Financial Accounting Standards Advisory Council (FASAC): Carrying out the Mission. http://www.fasb.org/fasac/ Accessed: 1/22/2013

Fields, T.D., Lys, T.Z., Vincent, L., 2001. Empirical research on accounting choice. Journal of Accounting and Economics 31, 255-307.

Gipper, Brandon, Brett J. Lombardi, and Douglas J. Skinner., 2013 The politics of accounting standard-setting: A review of empirical research. Australian Journal of Management 38.3, 523551

Grossman, G.M., Helpman, E., 2002. Special interest politics. Cambridge, Mass.: MIT.

Hall, R.L., Wayman, F.W., 1990. Buying time: Moneyed interests and the mobilization of bias in congressional committees. The American Political Science Review, 797-820.

Haring, J.R., Jr., 1979. Accounting rules and "The Accounting Establishment". The Journal of Business 52, 507-519. 
Holthausen, R.W., Leftwich, R.W., 1983. The economic consequences of accounting choice implications of costly contracting and monitoring. Journal of Accounting and Economics 5, 77117.

Hussein, M., Ketz, J.E., 1980. Ruling elites of the FASB: a study of the big eight. Journal of Accounting, Auditing \& Finance 3(4), 354-367.

Leftwich, R., 1995. The agenda of the financial accounting standards board. Working Paper-University of Chicago.

Lev, B., 1988. Toward a theory of equitable and efficient accounting policy. The Accounting Review 63(1), 1-22.

Miller, P.B.W., Redding, R.J., 1998. The FASB : the people, the process, and the politics, 4th ed. Homewood, Ill.: Irwin.

Pendergast, J.F., Gange, S.J., Newton, M.A., Lindstrom, M.J., Palta, M., Fisher, M.R., 1996. A survey of methods for analyzing clustered binary response data. International Statistical Review 64, 89-118.

Plott, C.R., 1976. Axiomatic social choice theory: An overview and interpretation. American Journal of Political Science 20, 511-596.

Puro, M., 1984. Audit firm lobbying before the Financial Accounting Standards Board: An empirical study. Journal of Accounting Research 22, 624-646.

Puro, M., 1985. Do large accounting firms collude in the standards-setting process? Journal of Accounting, Auditing \& Finance 8, 165-177.

Ramanna, K., 2008. The implications of unverifiable fair-value accounting: Evidence from the political economy of goodwill accounting. Journal of Accounting and Economics 45, 253-281.

Saemann, G.R., 1995. The accounting standard-setting due process, corporate Consensus, and FASB responsiveness: Employers' accounting for pensions. Journal of Accounting, Auditing \& Finance 10, 555-564.

U. S. Congress. 1976. Subcommittee on Reports, Accounting and Management, The Accounting Establishment, a Staff Study (Metcalf Report), 94th Congress, Second Sessions.

Van Riper, R., 1994. Setting standards for financial reporting: FASB and the struggle for control of a critical process: Quorum Books Westport, CT.

Watts, R.L., Zimmerman, J.L., 1978. Towards a positive theory of the determination of accounting standards. The Accounting Review 53, 112-134.

Watts, R.L., Zimmerman, J.L., 1981. Auditors and the determination of accounting standards: Monash University, Department of Accounting and Finance. 
Wilson, J.Q., 1980. The politics of regulation. New York: Basic Books.

Young, J., 2006. Making up users. Accounting Organizations and Society 31, 579-600.

Zeff, S., 1978. The rise of "economic consequences". Journal of Accountancy 56-63. 


\section{Appendix A: Illustrative excerpts from the 1998 and 2002 FASAC Surveys and associated Summaries of Responses.}

From 1982-2001 the annual FASAC Survey provided a list of potential projects for addition to the Board's agenda and asked respondents to score each topic according to a pre-defined Likert Scale. Participant responses to the Survey were subsequently presented to Board members in a document entitled "Summary of Responses to the Annual FASAC Survey" (hereafter Summary of Responses) that reported both average participant ratings as well as individual responses.

From 2002-2006 the annual FASAC Survey did not provide a list of potential projects but rather asked participants to write in the five projects they felt were most important for the Board to include on its agenda. Individual responses to the Survey as well as a tally of "Top-5" mentions afforded to each project were subsequently presented to Board members in the Summary of Responses.

Excerpts from the 1998 and 2002 FASAC Surveys and Summaries of Responses are provided in this appendix for illustrative purposes.

\section{$\underline{\text { Illustrative excerpts from } 1998}$}

\section{FASAC Survey instructions}

"The Board and staff receive many requests and suggestions to add items to the agenda from various sources, including FASAC, the AICPA, and the SEC, among others... This section asks your views on which subjects-if any - the Board should consider for addition to its agenda. The Board also would be interested in other topics, not listed, that you believe should be addressed...Please evaluate the topics in this section on a scale of 1 to 5, with " 1 " being the highest priority and "5" the lowest. A score of " 1 " would indicate... respondents are [also] encouraged to comment [qualitatively]"

\section{Summary of Responses}

“Comments provided by respondents about possible future agenda projects are detailed below.

\section{Accounting for Intangible Assets}

The average score by group of respondent is as follows

$\begin{array}{ll}\text { Council Members } & 2.94 \\ \text { Board Members } & 2.38\end{array}$

Comments provided by respondents and the score assigned by each were:

Ciesielski (1) There is a need for the project. There have been problems in this area for 30-plus years...Highest priority because (1) existing accounting is producing balance sheets that are not particularly meaningful...

Woodyatt (4) Worthwhile subject but should wait for decisions on business combinations project" 


\section{Illustrative excerpts from 2002}

\section{FASAC Survey instructions}

"The current financial reporting environment is one of uncertainty and transition affected by, among other things, corporate bankruptcies, accounting irregularities, and legislation to regulate the accounting profession. Given that environment, we think it is appropriate to begin the 2002 annual FASAC survey with a blank piece of paper. If the FASB was setting its agenda today, what are the five most important issues the Board should address? Please be as specific as possible and give the reasons for your response."

\section{Summary of Responses}

"The table below summarizes the five issues that appeared most often in Council members' responses. Board member responses are shown for comparison ..."

\begin{tabular}{|l|c|c|}
\hline \multicolumn{1}{|c|}{ Topic } & $\begin{array}{c}\text { Council } \\
\text { Members }\end{array}$ & $\begin{array}{c}\text { Board } \\
\text { Members }\end{array}$ \\
\hline Revenue Recognition & 19 & 7 \\
\hline Consolidations & 13 & 4 \\
\hline Codification and Simplification of Standards & 10 & 1 \\
\hline Financial Performance Reporting & 8 & 7 \\
\hline Business Combinations_Purchase Method Procedures & 7 & 1 \\
\hline & & \\
\hline
\end{tabular}

"Individual responses appear below. We have included a brief reference to the issues cited by the respondent, followed by more detailed comments (if any) on each issue.

Anderson Revenue Recognition

Financial Performance Reporting

Cash Flow Reporting

Disclosures about Intangibles

Accounting for Leases

Revenue recognition is a central accounting issue and the literature on revenue recognition has become inadequate as a result of...

$\cdots$

Wulff Simplification and Codification

Reporting Financial Performance

Revenue Recognition

Fair Value Measurement

ST International Convergence

Simplification and Codification: transitioning to principles-based standards..." 
Appendix B: Classification of financial FASAC into large and small constituencies by total assets.

Panel A: Total Assets Cutoff Value for big_fin by year (in \$millions)

\begin{tabular}{|c|c|c|c|c|c|c|c|c|c|c|}
\hline 1986 & 1987 & 1988 & 1989 & 1990 & 1991 & 1992 & 1993 & 1994 & 1995 & 1996 \\
\hline 2,746 & 2,761 & 3,474 & 3,791 & 4,608 & 4,023 & 4,618 & 4,975 & 5,770 & 6,645 & 6,708 \\
\hline 1997 & 1998 & 1999 & 2000 & 2001 & 2002 & 2003 & 2004 & 2005 & 2006 & \\
\hline 7,633 & 11,022 & 12,272 & 12,676 & 13,860 & 14,817 & 22,634 & 24,908 & 25,456 & 25,142 & \\
\hline
\end{tabular}

Panel B: Commenting FASAC member financial institutions

\begin{tabular}{|c|c|c|c|}
\hline \multirow{2}{*}{\multicolumn{2}{|c|}{ big_fin }} & \multicolumn{2}{|l|}{ little fin } \\
\hline & & \multicolumn{2}{|c|}{ Investment Banking/Management* } \\
\hline Bear Stearns \& Co. & $1989-1992$ & Grace \& White Inc. & $1979-1983$ \\
\hline Goldman Sachs \& Co. & $1998-2001$ & SoundView Financial Group & $1993-1994$ \\
\hline Bear Stearns \& Co. & $2002-2005$ & Harris Investment Management & $1995-1998$ \\
\hline J.P.Morgan Chase \& Co. & $2002-2005$ & Aubrey G. Lanston \& Co. & $2001-2004$ \\
\hline Capital Group & $2003-2006$ & William Blair \& Co. & $2003-2006$ \\
\hline Putnam Investments & $2004-2007$ & & \\
\hline \multicolumn{4}{|c|}{ Commercial Banking/Bank Holding Company* } \\
\hline Irving Trust Co. & $1980-1983$ & Florida National S\&L & $1980-1983$ \\
\hline Morgan Guaranty Trust Co. & $1982-1983$ & United Virginia Bank & $1981-1985$ \\
\hline Wachovia Bank & $1983-1987$ & Astoria Federal S\&L & $1987-1990$ \\
\hline Norwest Corp. & $1985-1986$ & Grundy National Bank & $1989-1992$ \\
\hline Citicorp & $1985-1988$ & Boston Savings Bank & $1991-1994$ \\
\hline First National Bank of Boston & $1987-1990$ & Grundy National Bank & $1992-1995$ \\
\hline BankAmerica Corp. & $1989-1992$ & Andover Bancorp & $1993-1996$ \\
\hline National Westminster Bank & $1992-1995$ & People's Bank & $1995-1998$ \\
\hline First Chicago Corp. & $1993-1996$ & Patelco Credit Union & $2003-2006$ \\
\hline Chase Manhattan Bank & 1993 - 1996 & & \\
\hline Bank of Boston & $1996-1999$ & & \\
\hline GE Capital & $1999-2002$ & & \\
\hline Wells Fargo Bank & $2006-2009$ & & \\
\hline \multicolumn{4}{|l|}{ Private Equity/Venture Capital } \\
\hline \multirow[t]{2}{*}{ Warburg Pincus } & $2006-2009$ & Greenspan O'Neil Associates & $1985-1988$ \\
\hline & & Crabtree Ventures & $2001-2004$ \\
\hline \multicolumn{4}{|l|}{ Insurance } \\
\hline Lincoln National Corp. & $1988-1991$ & New England Mutual Life & $1983-1987$ \\
\hline Aetna Life \& Casualty & $1992-1995$ & & \\
\hline C.N.A Financial & $1993-1996$ & & \\
\hline \multicolumn{4}{|l|}{ Pension Fund } \\
\hline US Steel and Carnegie Pension & 1993 - 1996 & & \\
\hline \multicolumn{4}{|l|}{ Rating Agency } \\
\hline Moody's & $1999-2002$ & Duff \& Phelps & $1989-1992$ \\
\hline Standard \& Poors & $2003-2006$ & Duff \& Phelps & $1996-1999$ \\
\hline Moody's & $2005-2008$ & & \\
\hline
\end{tabular}

*Post the Gramm-Leach-Bliley Act in 1999 financial holding companies may engage in both investment banking and commercial banking activities 


\section{Figure 1: FASAC composition by constituent group}

auditor is defined as any member currently employed in the public accounting profession, financial as any member currently employed in the banking, insurance, or securities industry, preparer as any member of business and industry not classified as auditor or user, and other as any member who does not fall into the category of auditor, financial, or preparer. See Section 3.3.2 for details.

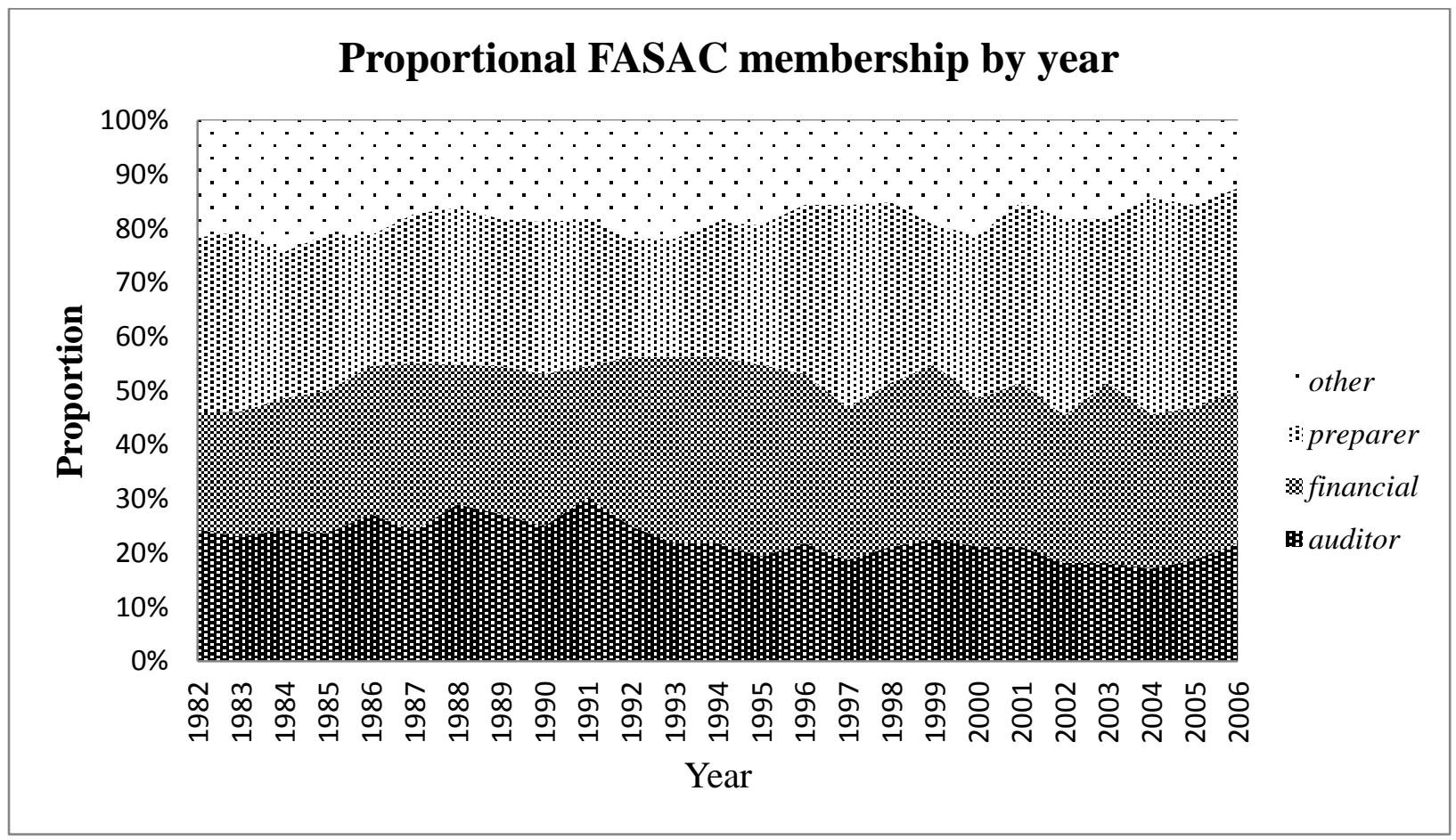


Table 1: Summary of response data for the FASAC Annual Questionnaire on the Projects and Priorities of the FASB

Panel A: 1982-2001: Priority ratings of prompted topics for future agenda inclusion

\begin{tabular}{|c|c|c|c|c|c|c|c|}
\hline Year $\wedge$ & $\begin{array}{l}\text { Potential } \\
\text { Projects } \\
\text { Included }\end{array}$ & $\begin{array}{c}\text { Scale } \\
\text { Granularity }\end{array}$ & \# FASAC & FASAC Responding & $\begin{array}{c}\text { Unique } \\
\text { Project } \\
\text { Evaluations }\end{array}$ & $\begin{array}{c}\text { FASB } \\
\text { Responding }\end{array}$ & $\begin{array}{c}\text { Visible Individual } \\
\text { Ratings }\end{array}$ \\
\hline 1982 & 6 & {$[1,3]$} & 37 & $33(89 \%)$ & 198 & No & 79 (40\%) \\
\hline 1983 & 6 & {$[1,3]$} & 39 & 35 (90\%) & 210 & No & 86 (41\%) \\
\hline 1984 \# & 7 & {$[1,3]$} & 37 & $29(78 \%)$ & 203 & No & $0(0 \%)$ \\
\hline 1985 & 6 & {$[1,2]$} & 38 & $28(74 \%)$ & 168 & No & 81 (48\%) \\
\hline 1986 & 12 & {$[1,2]$} & 33 & 28 (85\%) & 336 & No & 123 (37\%) \\
\hline 1987 & 18 & {$[1,2]$} & 29 & 23 (79\%) & 414 & No & 132 (32\%) \\
\hline 1989 & 20 & {$[1,2]$} & 33 & 27 (82\%) & 540 & No & $172(32 \%)$ \\
\hline 1990 & 21 & {$[8,1]$} & 32 & 27 (84\%) & 567 & No & 275 (49\%) \\
\hline 1991 & 21 & {$[1,8]$} & 33 & $28(85 \%)$ & 588 & No & 312 (53\%) \\
\hline 1992 & 23 & {$[1,8]$} & 32 & 22 (69\%) & 506 & No & 231 (46\%) \\
\hline 1993 & 23 & {$[1,8]$} & 32 & 26 (81\%) & 598 & No & $394(66 \%)$ \\
\hline 1994 & 23 & {$[1,8]$} & 32 & 27 (84\%) & 621 & No & 404 (65\%) \\
\hline 1995 & 20 & {$[1,8]$} & 31 & $26(84 \%)$ & 520 & No & 373 (72\%) \\
\hline 1998 & 10 & {$[1,5]$} & 33 & 18 (55\%) & 180 & Yes (100\%) & 161 (89\%) \\
\hline 1999 & 7 & {$[1,5]$} & 31 & 22 (71\%) & 154 & Yes $(100 \%)$ & $103(67 \%)$ \\
\hline $2001 \#$ & 19 & {$[1,3]$} & 33 & 22 (67\%) & 418 & Yes $(100 \%)$ & $0(0 \%)$ \\
\hline Total & 242 & & & 421 (79\%) & 6221 & & $2926(46 \%)$ \\
\hline
\end{tabular}

${ }^{\wedge}$ Data with which to construct my variable for aggregate FASAC preferences (FASAC_pref) during the 19822001 period are unavailable for four years: 1988 (no FASAC survey); 1996 and 1997 (FASAC survey did not address "Potential Agenda Items"); 2000 (survey res pondents ranked rather than independently rated \# Data with which to construct my variables for disaggregated FASAC preferences by constituent group (aud_pref,fin_pref, and ind_pref) are unavailable for two years: in 1984 and 2001, individual qualitative responses, but not quantitative ratings, are visible in the Summary of FASAC Annual Survey Responses.

Panel B: 2002-2006: Free Response top 5 priorities for future agenda projects

\begin{tabular}{|c|c|c|c|c|c|c|c|}
\hline Year & $\begin{array}{l}\text { Potential } \\
\text { Projects } \\
\text { Mentioned }\end{array}$ & $\begin{array}{c}\text { Scale } \\
\text { Granularity }\end{array}$ & \# FASAC & FASAC Responding & $\begin{array}{c}\text { Unique } \\
\text { Project } \\
\text { Mentions }\end{array}$ & $\begin{array}{c}\text { FASB } \\
\text { Responding }\end{array}$ & $\begin{array}{c}\text { Individual Top } 5 \\
\text { Visible }\end{array}$ \\
\hline 2002 & 20 & Top 5 & 33 & $22(67 \%)$ & 440 & Yes (100\%) & Yes $(100 \%)$ \\
\hline 2003 & 16 & Top 5 & 33 & 27 (82\%) & 432 & Yes $(100 \%)$ & Yes (100\%) \\
\hline 2004 & 16 & Top 5 & 35 & $28(80 \%)$ & 448 & Yes $(100 \%)$ & Yes $(100 \%)$ \\
\hline 2005 & 15 & Top 5 & 32 & 27 (84\%) & 405 & Yes $(100 \%)$ & Yes $(100 \%)$ \\
\hline 2006 & 14 & Top 5 & 32 & 31 (97\%) & 434 & Yes $(100 \%)$ & Yes $(100 \%)$ \\
\hline Total & 81 & & & 135 (82\%) & 2159 & & 2159 (100\%) \\
\hline
\end{tabular}


Table 2: Distribution of FASAC Survey commenting members and total FASAC member composition (1982-2001)

Sample is the 2926 individual survey responses visible in the Summary of Responses to the 1982-2001 FASAC annual surveys (see Section 3.1) auditor is defined as any member currently employed in the public accounting profession, financial as any member currently employed in the banking, insurance, or securities industry, preparer as any member of business and industry not classified as auditor or user, and other as any member who does not fall into the category of auditor, financial, or preparer. See Section 3.3.2 for details.

\begin{tabular}{|c|c|c|c|c|c|}
\hline \multicolumn{3}{|c|}{$\begin{array}{l}\text { Distribution of Visible Individual } \\
\text { Response Data by Constituent Group }\end{array}$} & \multicolumn{3}{|c|}{$\begin{array}{l}\text { Average Annual Distribution of All } \\
\text { FASAC Members by Constituent Group }\end{array}$} \\
\hline Auditor & 812 & $28 \%$ & Auditor & 8 & $24 \%$ \\
\hline Preparer & 813 & $28 \%$ & Preparer & 9 & $27 \%$ \\
\hline Financial & 784 & $27 \%$ & Financial & 10 & $30 \%$ \\
\hline Others & 517 & $18 \%$ & Others & 6 & $18 \%$ \\
\hline Total & 2926 & $100 \%$ & Total & 33 & $100 \%$ \\
\hline
\end{tabular}




\section{Table 3 Summary statistics and Pearson correlation coefficients}

Sample is 343 potential projects about which FASAC member preferences were collected in the 1982-2006 FASAC annual surveys. agenda_add is a binary variable that takes the value of 1 for potential projects added to the FASB's agenda within one year of the annual FASAC survey on which it was included; fasac_pref is the average priority rating given a potential project by all FASAC members participating in the FASAC annual survey; fasb_pref is the average priority rating given a potential project by all FASB members participating in the FASAC annual survey; fasb_proxy is a binary variable that takes the value of 1 if a potential project was mentioned in FASB status reports in the year preceding the FASAC annual survey; aud_pref, fin_pref, prep_pref, and other_pref are the average priority ratings assigned to a potential project by FASAC members classified as auditor, financial, preparer, or other, respectively, as defined in Section 3.3; big_aud, little_aud, big_fin, little_fin, big_prep, and little_prep are the average preferences assigned to a potential project by auditor, financial, and preparer FASAC members, respectively, and separated by size according to the criteria described in Section 3.3.3. See Sections 3.2-3.4 for details.

\section{Panel A: Summary statistics (dependent variables)}

\begin{tabular}{|l|r|r|r|r|r|r|}
\hline $1982-2001$ & $\mathrm{n}$ & \multicolumn{1}{c}{ Mean } & Med & \multicolumn{2}{c}{ Std } & \multicolumn{2}{c}{ Min } & \multicolumn{2}{c}{ Max } \\
\hline$Y=$ agenda_addition & 242 & 0.07 & 0.00 & 0.26 & 0.00 & 1.00 \\
\hline
\end{tabular}

\begin{tabular}{|l|r|r|r|r|r|r|}
$2002-2006(\mathrm{n}=81)$ & $\mathrm{n}$ & \multicolumn{1}{c}{ Mean Med } & \multicolumn{1}{c}{ Std } & Min & Max \\
\hline$Y=$ agenda_addition & 81 & 0.09 & 0.00 & 0.28 & 0.00 & 1.00 \\
\hline
\end{tabular}

\section{Panel B: Summary statistics (independent variables)}

\begin{tabular}{|l|r|r|r|r|r|r|}
\hline 1982-2001 & \multicolumn{1}{c}{ Mean } & Med & \multicolumn{2}{l}{ Std } & \multicolumn{1}{c}{ Min } & \multicolumn{1}{c}{ Max } \\
\hline fasac_pref & 242 & 0.39 & 0.38 & 0.16 & 0.03 & 0.85 \\
\hline \hline aud_pref & 186 & 0.43 & 0.40 & 0.26 & 0.00 & 1.00 \\
\hline fin_pref & 186 & 0.45 & 0.46 & 0.24 & 0.00 & 1.00 \\
\hline prep_pref & 186 & 0.34 & 0.31 & 0.24 & 0.00 & 1.00 \\
\hline other_pref & 186 & 0.51 & 0.52 & 0.28 & 0.00 & 1.00 \\
\hline \hline big_aud & 94 & 0.51 & 0.50 & 0.27 & 0.00 & 1.00 \\
\hline little_aud & 94 & 0.39 & 0.38 & 0.32 & 0.00 & 1.00 \\
\hline big_fin & 94 & 0.47 & 0.50 & 0.26 & 0.00 & 1.00 \\
\hline little_fin & 94 & 0.55 & 0.57 & 0.30 & 0.00 & 1.00 \\
\hline big_prep & 94 & 0.37 & 0.33 & 0.24 & 0.00 & 1.00 \\
\hline little_prep & 94 & 0.39 & 0.36 & 0.33 & 0.00 & 1.00 \\
\hline \hline fasb_proxy & 242 & 0.10 & 0.00 & 0.30 & 0.00 & 1.00 \\
\hline fasb_pref & 36 & 0.48 & 0.50 & 0.22 & 0.06 & 1.00 \\
\hline sec_proxy & 242 & 0.05 & 0.22 & 0.00 & 0.00 & 1.00 \\
\hline iasb & 242 & 0.16 & 0.36 & 0.00 & 0.00 & 1.00 \\
\hline
\end{tabular}

\begin{tabular}{|l|r|r|r|r|r|r|} 
2002-2006 & $\mathrm{n}$ & \multicolumn{1}{c}{ Mean } & Med & \multicolumn{2}{c}{ Std } & \multicolumn{2}{c}{ Min } & Max \\
\hline fasac_pref & 81 & 0.09 & 0.05 & 0.11 & 0.00 & 0.59 \\
\hline \hline aud_pref & 81 & 0.12 & 0.00 & 0.17 & 0.00 & 0.83 \\
\hline fin_pref & 81 & 0.10 & 0.00 & 0.15 & 0.00 & 0.75 \\
\hline prep_pref & 81 & 0.06 & 0.00 & 0.11 & 0.00 & 0.50 \\
\hline other_pref & 81 & 0.10 & 0.00 & 0.15 & 0.00 & 0.50 \\
\hline big_aud & 81 & 0.12 & 0.00 & 0.21 & 0.00 & 1.00 \\
\hline little_aud & 81 & 0.13 & 0.00 & 0.26 & 0.00 & 1.00 \\
\hline big_fin & 81 & 0.12 & 0.00 & 0.19 & 0.00 & 0.83 \\
\hline little_fin & 81 & 0.06 & 0.00 & 0.15 & 0.00 & 0.67 \\
\hline big_prep & 81 & 0.06 & 0.00 & 0.12 & 0.00 & 0.50 \\
\hline little_prep & 81 & 0.07 & 0.00 & 0.17 & 0.00 & 0.50 \\
\hline fasb_proxy & 81 & 0.20 & 0.00 & 0.40 & 0.00 & 1.00 \\
\hline fasb_pref & 81 & 0.10 & 0.00 & 0.14 & 0.00 & 0.57 \\
\hline sec_proxy & 81 & 0.17 & 0.38 & 0.00 & 0.00 & 1.00 \\
\hline iasb & 81 & 0.25 & 0.43 & 0.00 & 0.00 & 1.00 \\
\hline
\end{tabular}


Table 3 (continued)

\begin{tabular}{|c|c|c|c|c|c|c|c|c|c|c|c|}
\hline Panel & \multicolumn{3}{|c|}{ C: } & & Pearson & \multicolumn{4}{|c|}{ correlation } & \multicolumn{2}{|r|}{ coefficients } \\
\hline 1982-1999 & & & & & & 2002-2006 & & & & & \\
\hline \multirow[t]{2}{*}{$\mathrm{n}=186$} & & & & & & $n=81$ & & & & & \\
\hline & aud_pref & fin_pref & prep_pref & & & & aud_pref & fin_pref & prep_pref & & \\
\hline fin_pref & 0.06 & & & & & fin_pref & $0.47^{* * *}$ & & & & \\
\hline prep_pref & $0.31 * * *$ & $0.28 * * *$ & & & & prep_pref & $0.52 * * *$ & $0.65 * * *$ & & & \\
\hline other_pref & $0.26 * * *$ & $0.29 * * *$ & $0.32 * * *$ & & & other_pref & $0.20 *$ & $0.21 *$ & $0.33 * * *$ & & \\
\hline \multirow[t]{2}{*}{$n=94$} & & & & & & $n=81$ & & & & & \\
\hline & big_aud & little_aud & big_fin & little_fin & big_prep & & big_aud & little_aud & big_fin & little_fin & big_prep \\
\hline little_aud & $0.43^{* * *}$ & & & & & little_aud & $0.35^{* * *}$ & & & & \\
\hline big_fin & 0.13 & 0.06 & & & & big_fin & $0.35 * * *$ & $0.55 * * *$ & & & \\
\hline little_fin & -0.02 & 0.00 & 0.14 & & & little_fin & 0.13 & 0.08 & $0.20 * *$ & & \\
\hline big_prep & $0.38 * * *$ & $0.23 * *$ & $0.39^{* * *}$ & $0.25 * *$ & & big_prep & $0.36 * * *$ & $0.43 * * *$ & $0.58 * * *$ & $0.33 * * *$ & \\
\hline little_prep & $0.22 * *$ & $0.30 * * *$ & $0.30^{* * *}$ & $0.21 * *$ & $0.56 * * *$ & little_prep & 0.16 & $0.43^{* * *}$ & $0.46 * * *$ & 0.09 & $0.38 * * *$ \\
\hline
\end{tabular}




\section{Table 4: FASB agenda decisions on aggregate FASAC preferences}

Sample is 242 (Panel A) and 81 (Panel B) potential projects about which FASAC member preferences were collected in the 1982-2001 and 2002-2006 FASAC annual surveys, respectively. agenda_add is a binary variable that takes the value of 1 for potential projects added to the FASB's agenda within one year of the annual FASAC survey on which it was included; fasac_pref is the average priority rating given a potential project by all FASAC members participating in the FASAC annual survey; fasb_pref is the average priority rating given a potential project by all FASB members participating in the FASAC annual survey; fasb_proxy is a binary variable that takes the value of 1 if a potential project was mentioned in FASB status reports in the year preceding the FASAC annual survey; sec_proxy is a binary variable that takes the value of 1 for potential projects mentioned favorably by the SEC in its annual report or at quarterly FASAC meetings. See Sections 3.2-3.4 for details.

Panel A: 1982-2001^

$Y=$ agenda_addition $(t+1)$

(1)

fasac_pref

fasb_proxy

sec_proxy

iasb

Conditional FE

S.E. (Cluster)

Pseduo R-sq

$\mathrm{n}$

Significance levels $\left(^{*}\right) 10 \%$ level, $\left({ }^{* *}\right) 5 \%$ level, $\left({ }^{* *}\right) 1 \%$ level using a 2 tailed test.

${ }^{\wedge}$ Excludes 1988, when no FASAC survey was conducted; 1996 and 1997, when the FASAC survey did not ask about potential projects; and 2000, due to inconsistent survey structure. See Table 2 for details.

Panel B: 2002-2006

$Y=$ agenda_addition $(t+1)$

fasac_pref

fasb_pref

sec_proxy

iasb

Conditional FE

S.E. (Cluster)

Pseduo R-sq

\section{$\mathrm{n}$}

(2)

\begin{tabular}{l|l|l|l|l|l|}
\hline $5.44^{* * *}$ & $4.85^{* * *}$ & $3.79^{*}$ & $3.17^{*}$ & $\begin{array}{l}3.27^{*} \\
1.80 * *\end{array}$ & $\begin{array}{l}3.16^{*} \\
1.59^{* *}\end{array}$ \\
& & $1.44^{* *}$ & $1.35^{* *}$ & 1.30 & $2.47^{* *}$ \\
& & & & $1.09^{*}$ & $1.57^{* *}$ \\
& & & & & \\
None & & & & None & Year \\
Year & Year & None & Year & Year & Year \\
0.10 & 0.12 & Year & Year & 0.18 & 0.27 \\
242 & 143 & 242 & 0.16 & 242 & 143 \\
\hline
\end{tabular}

Significance levels $\left({ }^{*}\right) 10 \%$ level, $\left({ }^{* *}\right) 5 \%$ level, $\left({ }^{* * *}\right) 1 \%$ level using a 2 tailed test. 
Table 5: FASB agenda decisions on auditor, financial, preparer, and other constituent preferences

Sample is 242 (Panel A) and 81 (Panel B) potential projects about which FASAC member preferences were collected in the 1982-2001 and 2002-2006 FASAC annual surveys, respectively. agenda_add is a binary variable that takes the value of 1 for potential projects added to the FASB's agenda within one year of the annual FASAC survey on which it was included; aud_pref, fin_pref, prep_pref, and other_pref are the average priority ratings assigned to a potential project by FASAC members classified as auditor, financial, preparer, or other, respectively, as defined in Section 3.3; fasb_pref is the average priority rating given a potential project by all FASB members participating in the FASAC annual survey; fasb_proxy is a binary variable that takes the value of 1 if a potential project was mentioned in FASB status reports in the year preceding FASAC annual survey; sec_proxy is a binary variable that takes the value of 1 for potential projects mentioned favorably by the SEC in its annual report or at quarterly FASAC meetings. See Sections 3.2-3.4 for details.

Panel A: 1982-2001^

\begin{tabular}{|c|c|c|c|c|c|c|}
\hline$Y=$ agenda_addition $(t+1)$ & $(1)$ & $(2)$ & $(3)$ & (4) & $(5)$ & $(6)$ \\
\hline aud_pref & $2.62 * *$ & $3.34 *$ & $2.40 * *$ & $3.04 *$ & $2.60 * *$ & $3.91 * * *$ \\
\hline fin_pref & $2.08 *$ & $2.78^{* *}$ & $1.95 *$ & $2.74 * *$ & $1.94 *$ & $2.14 *$ \\
\hline prep_pref & 0.58 & -0.82 & 0.15 & -1.74 & -0.17 & -2.54 \\
\hline other_pref & -1.60 & -1.62 & -1.54 & -1.77 & -1.49 & -1.36 \\
\hline fasb_proxy & & & $1.19 *$ & 1.42 & $1.49 * *$ & $2.03 * *$ \\
\hline sec_proxy & & & & & $1.59 *$ & $2.94 * * *$ \\
\hline$i a s b$ & & & & & 0.74 & $1.23 *$ \\
\hline Conditional FE & None & Year & None & Year & None & Year \\
\hline S.E. (Cluster) & Year & Year & Year & Year & Year & Year \\
\hline Pseduo R-sq & 0.09 & 0.16 & 0.12 & 0.20 & 0.15 & 0.31 \\
\hline $\mathrm{n}$ & 186 & 111 & 186 & 111 & 186 & 111 \\
\hline
\end{tabular}

Significance levels $\left({ }^{*}\right) 10 \%$ level, $\left({ }^{* *}\right) 5 \%$ level, $\left({ }^{* * *}\right) 1 \%$ level using a 2 tailed test.

^Excludes 1984 and 2001, because individual numerical scores were not provided; 1988, when no survey was conducted; 1996 and 1997, during which years the survey did not discuss potential projects; and 2000, due to inconsistent survey structure. See Table 2 for details.

Panel B: 2002-2006

\begin{tabular}{|c|c|c|c|c|c|c|}
\hline$Y=$ agenda_addition $(t+1)$ & $(1)$ & $(2)$ & $(3)$ & (4) & $(5)$ & $(6)$ \\
\hline aud_pref & -0.48 & -2.01 & -1.58 & -6.39 & -2.36 & -6.34 \\
\hline fin_pref & $8.88 * *$ & $15.79 * * *$ & $7.01 *$ & $21.37 * * *$ & $9.96 * *$ & $20.79 * * *$ \\
\hline prep_pref & 1.55 & 1.71 & 3.32 & 5.72 & 6.51 & 6.67 \\
\hline other_pref & 0.55 & 2.05 & 0.38 & 3.55 & 3.84 & 3.65 \\
\hline fasb_pref & & & 3.73 & $7.99 * *$ & 4.97 & $7.58 * *$ \\
\hline sec_proxy & & & & & -2.43 & -0.52 \\
\hline$i a s b$ & & & & & -2.92 & -0.44 \\
\hline Conditional FE & None & Year & None & Year & None & Year \\
\hline S.E. (Cluster) & Year & Year & Year & Year & Year & Year \\
\hline Pseduo R-sq & 0.34 & 0.55 & 0.37 & 0.64 & 0.46 & 0.64 \\
\hline $\mathrm{n}$ & 81 & 67 & 81 & 67 & 81 & 67 \\
\hline
\end{tabular}

Significance levels $\left({ }^{*}\right) 10 \%$ level, $\left({ }^{* *}\right) 5 \%$ level, $\left({ }^{* * *}\right) 1 \%$ level using a 2 tailed test. 
Table 6: FASB agenda decisions on auditor, financial, preparer, and other constituent preferences disaggregated by size

Sample is 242 (Panel A) and 81 (Panel B) potential projects about which FASAC member preferences were collected in the 1982-2001 and 2002-2006 FASAC annual surveys respectively. agenda_add is a binary variable that takes the value of 1 for potential projects added to the FASB's agenda within one year of the annual FASAC survey on which it was included; aud_pref, fin_pref, prep_pref, and other_pref are the average priority ratings assigned to a potential project by FASAC members classified as auditor, financial, preparer, or other, respectively, as defined in Section 3.3; fasb_pref is the average priority rating given a potential project by all FASB members participating in the FASAC annual survey; fasb_proxy is a binary variable that takes the value of 1 if a potential project was mentioned in FASB status reports in the year preceding the FASAC annual survey; sec_proxy is a binary variable that takes the value of 1 for potential projects mentioned favorably by the SEC in its annual report or at quarterly FASAC meetings. See Sections 3.2-3.4 for details.

Panel A: 1982-2001

$Y=$ agenda_addition $(t+1)$

(1)

\begin{tabular}{|c|c|c|c|c|c|c|}
\hline big_aud & $2.27 * *$ & $4.49 * * *$ & $2.29 * *$ & $4.73 * * *$ & $2.61 * *$ & $4.91 * * *$ \\
\hline little_aud & 0.57 & -0.38 & 0.60 & -0.50 & 0.71 & -0.37 \\
\hline big_fin & -0.59 & 1.36 & -0.73 & 0.81 & -0.84 & 0.31 \\
\hline little fin & -0.58 & -0.41 & -0.52 & -0.09 & -0.60 & 0.33 \\
\hline big_ind & 0.51 & -3.62 & 0.51 & -4.39 & -0.07 & -5.46 \\
\hline little_ind & 0.49 & 0.99 & 0.13 & 0.39 & 0.09 & 0.53 \\
\hline other_pref & -0.58 & -0.64 & -0.47 & 0.31 & -0.36 & -0.26 \\
\hline fasb_proxy & & & 0.70 & 1.76 & 0.87 & $1.82 * *$ \\
\hline sec_proxy & & & & & 1.01 & 0.99 \\
\hline iasb & & & & & $1.41 * *$ & 1.64 \\
\hline Conditional FE & None & Year & None & Year & None & Year \\
\hline S.E. (Cluster) & Year & Year & Year & Year & Year & Year \\
\hline Pseduo R-sq & 0.08 & 0.16 & 0.09 & 0.20 & 0.14 & 0.28 \\
\hline $\mathrm{n}$ & 94 & 52 & 94 & 52 & 94 & 52 \\
\hline
\end{tabular}

Significance levels (*) $10 \%$ level, $\left({ }^{* *}\right) 5 \%$ level, $\left({ }^{* * *}\right) 1 \%$ level using a 2 tailed test.

^Excludes 1984 and 2001, because individual numerical scores were not provided; 1988, when no survey was conducted; 1996 and 1997, during which years the survey did not discuss potential projects; and 2000, due to inconsistent survey structure. See Table 2 for details. 
Table 6 (continued):

Panel B: 2002-2006

$Y=$ agenda_addition $(t+1)$

big_aud

little_aud

big_fin

little fin

big_ind

little_ind

other_pref

fasb_pref

sec_proxy

iasb

Conditional FE

S.E. (Cluster)

Pseduo R-sq

(1)

(2)

(3)

(4)

(5)

\begin{tabular}{c|c|c|c|c|c|}
0.60 & 0.49 & -0.24 & -1.61 & 0.65 & -1.57 \\
-1.27 & -1.61 & -0.84 & -1.05 & -0.62 & -1.46 \\
5.06 & $7.33 *$ & 4.12 & $7.61 *$ & $7.67 * *$ & $7.80 * *$ \\
$4.30 *$ & $6.27 * *$ & 3.57 & $6.91 * *$ & $7.97 * * *$ & $7.10 * *$ \\
2.86 & 1.53 & 3.50 & 2.21 & 2.21 & 2.24 \\
-0.13 & 0.19 & 0.09 & 0.49 & -2.35 & 0.70 \\
1.51 & 1.85 & 1.12 & 2.13 & 7.52 & 2.23 \\
& & & & & \\
& & 2.67 & 5.00 & 3.84 & 5.23 \\
& & & & -0.63 & 0.54 \\
& & & & -0.64 & \\
None & Year & None & Year & None & Year \\
Year & Year & Year & Year & Year & Year \\
0.34 & 0.50 & 0.35 & 0.54 & 0.36 & 0.54 \\
81 & 67 & 81 & 67 & 81 & 67 \\
\hline
\end{tabular}

Significance levels (*) $10 \%$ level, $\left({ }^{* *}\right) 5 \%$ level, $\left({ }^{* * *}\right) 1 \%$ level using a 2 tailed test.

$\wedge$ Log-likelihood function is not concave when iasb is included in column (6) estimation. 


\section{Table 7: Re-estimation of Table 5 Columns (6) after controlling for finance related agenda}

topics

Sample is 111 (Column 1) and 67 (Column 2) potential projects used for estimation in Table 5 Panels A and B Column (6). agenda_add is a binary variable that takes the value of 1 for potential projects added to the FASB's agenda within one year of the annual FASAC survey on which it was included; aud_pref, fin_pref, prep_pref, and other_pref are the average priority ratings assigned to a potential project by FASAC members classified as auditor, financial, preparer, or other, respectively, as defined in Section 3.3; fasb_pref is the average priority rating given a potential project by all FASB members participating in the FASAC annual survey; fasb_proxy is a binary variable that takes the value of 1 if a potential project was mentioned in FASB status reports in the year preceding FASAC annual survey; sec_proxy is a binary variable that takes the value of 1 for potential projects mentioned favorably by the SEC in its annual report or at quarterly FASAC meetings. fin_issue is a binary variable which takes a value of 1 for potential projects pertaining to financial transactions. See Sections 3.2-3.4 and 6.1 for details.

(1)

(2)

\begin{tabular}{l|c|c|} 
Y=agenda_addition $(t+1)$ & 1982-2001 & 2002-2006 \\
\hline \hline aud_pref & $4.02^{* *}$ & -5.16 \\
fin_pref & 3.07 & $16.25^{* * *}$ \\
prep_pref & -2.68 & 6.57 \\
other_pref & -1.43 & 2.87 \\
& & \\
fasb_proxy & $1.94^{* *}$ & $6.40 * * *$ \\
sec_proxy & $3.12^{* * *}$ & -2.89 \\
iasb & $1.45^{*}$ & -0.16 \\
& & \\
fin_issue & 1.51 & $-42.70 * * *$ \\
fin_pref*fin_issue & -1.57 & $105.50 * * *$ \\
& & \\
Conditional FE & None & Year \\
S.E. (Cluster) & Year & Year \\
Pseduo R-sq & 0.32 & 0.66 \\
$\mathrm{n}$ & 111 & 67 \\
\hline
\end{tabular}

Significance levels $(*)$ ) $10 \%$ level, $\left({ }^{* *}\right) 5 \%$ level, $\left({ }^{* *}\right)$

$1 \%$ level using a 2 tailed test. 